\title{
COEXISTENCE OF SIMILAR SPECIES IN A SPACE-LIMITED INTERTIDAL ZONE
}

\author{
Steven R. Dudgeon, ${ }^{1,4}$ Robert S. Steneck, ${ }^{2}$ IAn R. Davison, ${ }^{2}$ and Robert L. Vadas ${ }^{3}$ \\ 'Department of Biology, Leidy Laboratories, University of Pennsylvania, Philadelphia, Pennsylvania 19104-6018 USA \\ ${ }^{2}$ School of Marine Science, University of Maine, Orono, Maine 04469 USA \\ ${ }^{3}$ Department of Plant Biology, University of Maine, Orono, Maine 04469 USA
}

\begin{abstract}
The lower intertidal zone $(0.0$ to $+1.0 \mathrm{~m}$ mean low water [MLW] $)$ of rocky shores in New England is a space-limited community occupied by two similar rhodophyte seaweeds, Chondrus crispus and Mastocarpus stellatus, that overlap broadly in their use of three essential resources: space, light, and nutrients. C. crispus coexists primarily with the prostrate-crust generation of $M$. stellatus lower on the shore (less than $+0.35 \mathrm{~m} \mathrm{MLW}$ ) and with the alternate upright-frond generation higher on the shore (greater than $+0.35 \mathrm{~m}$ MLW). Our objectives were to determine (1) whether these two species compete and (2) if so, what process(es) enable their coexistence. Upright fronds of $\boldsymbol{M}$. stellatus transplanted to the lowest intertidal zone (less than $+0.25 \mathrm{~m}$ MLW) where $C$. crispus predominates grew faster and showed higher survivorship after $2 \mathrm{yr}$ than those transplanted to areas where $M$. stellatus predominates. However, the failure of upright fronds of $M$. stellatus to consistently recruit limits their abundance in the lowest zone and reduces the frequency of preemptive competition by $C$. crispus. Moreover, when $M$. stellatus was grown in combination with fronds of $C$. crispus in this zone, the dominant competitor $C$. crispus suppressed the growth and reproductive output of $M$. stellatus fronds. Neither species was significantly consumed by littorinid gastropods in field and laboratory experiments, indicating that herbivory does not control patterns of coexistence. In the low zone, coexistence between $C$. crispus and $M$. stellatus appears to be mediated primarily by disturbances from winter storm waves that remove large, fast-growing $C$. crispus fronds and limit its abundance. Coexistence of $C$. crispus fronds and $M$. stellatus crusts in this zone may also result from their different patterns of resource use. In contrast to the low zone, the slow growth of $C$. crispus in the mid-low zone (approximately $+0.5 \mathrm{~m} \mathrm{MLW)} \mathrm{prevented} \mathrm{the} \mathrm{overgrowth}$ of fronds of $M$. stellatus and, hence, prevented competition from occurring during the growing season (spring, summer, fall). Our evidence suggests that disturbances from herbivores or waves cause little mortality of fronds in this zone or higher on the shore. Rather, in response to physiological stress, $C$. crispus sloughs off metabolically unproductive apical tissue prior to resuming growth in the spring, minimizing the chance of overgrowth by these fronds in the coming growing season. Together, these results suggest that the low production, rather than high mortality, of $C$. crispus fronds enables these competitors to coexist higher on the shore. On space-limited temperate rocky shores similar species often coexist because mortality from disturbances falls most heavily on the dominant competitor. Our results imply that coexistence of these species can be maintained by factors affecting the productivity, rather than the mortality, of the dominant competitor. But both sorts of processes may be important, as different processes may control coexistence of the same competitors in different environments.
\end{abstract}

Key words: Chondrus; coexistence; competition; disturbance; intertidal; Maine; Mastocarpus; productivity; recruitment; regeneration.

\section{INTRODUCTION}

Ecologically similar species (i.e., those that share resources) should compete intensely, but they often coexist indefinitely because of organismal traits or ecological processes that reduce competition or prevent it

Manuscript received 24 November 1997; revised 2 April 1998; accepted 13 May 1998; final version received 8 July 1998.

${ }^{4}$ Present address: Department of Biology, California State University, 18111 Nordhoff Street, Northridge, California 91330-8303 USA. E-mail: steve.dudgeon@ csun.edu from occurring. Slight differences in morphology, physiology, or life history traits can reduce competition between similar species by partitioning their shared spectrum of resources in character, time, and/or space. But many generalist species, particularly those in the marine realm, have broadly overlapping patterns of resource use (Paine 1977, Connell 1978). Among such taxa, three types of ecological processes enable coexistence of competitors: (1) processes that contribute to the local productivity of species (Grime 1979, Huston 1979, Levins 1979, Armstrong and McGehee 1980, Wilson and Keddy 1986, Tilman 1987, 1988, Keddy 
1989, Wilson and Tilman 1991), (2) physical or chemical stress (hereafter stress; Menge and Sutherland 1987, Bertness 1989, Bertness and Hacker 1994), or (3) disturbance (biotic or abiotic; Paine 1966, Dayton 1971, Caswell 1978, Connell 1978, Sousa 1979, Paine and Levin 1981).

These processes enable coexistence by disproportionately affecting the individual growth rates and the per capita birth or death rates of the dominant, relative to subordinate, competitors (Petraitis et al. 1989), but they act in different ways. The supplies of propagules to a patch, and resources to established individuals, determine the productivities per area of species and the potential for competition (Grime 1979, Underwood and Denley 1984, Menge and Sutherland 1987, Roughgarden et al. 1988). In contrast, exposure to stress (e.g., in aquatic organisms, freezing, desiccation, or osmotic shock) can either reduce productivity and growth of individuals indirectly by causing a metabolic dysfunction that constrains resource acquisition, or alter mortality rates if the exposure is lethal. Disturbances, on the other hand, can simultaneously alter per capita birth and death rates. The removal of biomass from the community in discrete pulse events kills individuals, or parts thereof in clonal taxa (i.e., partial mortality sensu Hughes and Jackson 1980), and may also reallocate space for colonization. Under these definitions, stress and disturbance are difficult to distinguish either when exposure to a particular stress is lethal, or when repeated exposures (i.e., chronic stress) over time cause partial or true mortality.

The prevailing view of species coexistence in spacelimited communities like marine hard-substrate communities, is that mortality caused by disturbances (e.g., predators or hydrodynamic forces of storm waves) falls most heavily on the dominant competitor thereby creating space for other rapidly colonizing, but often competitively inferior species (Paine 1966, Dayton 1971, Paine 1974, Menge 1976, Connell 1978, Lubchenco 1978, Lubchenco and Menge 1978, Witman 1985, 1987). This paradigm of disturbance-generated mortality and space allocation holds for communities composed largely of unitary plants and animals (e.g., barnacles, mussels, and kelps like Laminaria or Postelsia). However, this hypothesis is not sufficient to explain coexistence among populations of clonal seaweeds. Disturbances to populations of clonal seaweeds typically neither cause mortality of genetic individuals (genets), nor do they commonly create space for colonization by other species because the perennial holdfast encrusting the substrate remains intact (e.g., Chondrus crispus; Mathieson and Burns 1975, Lubchenco 1980, Dudgeon et al. 1990). Moreover, clonal seaweeds produce individual fronds or shoots repeatedly from the holdfast and thereby often comprise much of the biomass on rocky shores (Vadas and Manzer 1971) without sustained recruitment of germlings (e.g., Vadas et al. 1990). Instead of recruitment limitation or partial mortality caused by disturbances, populations of competitively dominant clonal seaweeds may be controlled either by physiological stress or the supply of resources both of which limit primary production (Grime 1979). These processes can also compromise the competitive ability of a dominant species and thereby mediate the coexistence of seaweed populations. The particular process(es) that limits the abundance of a dominant competitor and mediates its coexistence with other species may differ in different environments.

On many rocky shores on both sides of the north Atlantic Ocean two clonal red seaweeds, Chondrus crispus Stackhouse and Mastocarpus stellatus Stack. In With. (Guiry), codominate the lower intertidal zone (Burns and Mathieson 1972, Mathieson and Burns 1975, Dudgeon et al. 1989, 1995, Guiry and Garbary 1990, Lüning 1990, Dudgeon and Johnson 1992, Vadas and Elner 1992). Previous studies of the New England intertidal zone implicate $C$. crispus as the dominant competitor on emergent rock among all seaweeds (Lubchenco and Menge 1978, Lubchenco 1980). However, at many sites in the Gulf of Maine, the spatial overlap between $C$. crispus and $M$. stellatus spans approximately one vertical meter of tidal elevation. Our objectives were to determine (1) if these two species compete and (2) if so, what processes enable their coexistence in different parts of their overlapping intertidal distribution. A transplant experiment of $M$. stellatus and observations of growth patterns assessed how well each species survived and grew in different intertidal environments. We designed experiments to test the nature of the interaction between $C$. crispus and $M$. stellatus, specifically, if the outcome (dominance vs. coexistence) of a putative competition between them varied in environments that differed in exposure to stress and the supply of resources (i.e., does physiological stress and/or productivity of the species mediate their coexistence). Through observations and field and laboratory experiments, we tested an alternative hypothesis that disturbances, principally from herbivores underlay these patterns of coexistence.

We hypothesized that different processes mediate their putative competitive interaction at the high and low ends of the lower intertidal zone for two reasons. First, the mechanism of competition and/or the demand for resources may vary with algal morphology such as the different morphs exhibited by $M$. stellatus. The life history of $M$. stellatus consists of upright frond and crustose alternate generations that show different distributions within the zone of overlap with $C$. crispus (see Results). Second, environments at the top and bottom of the intertidal zone are different and they define a range of gradients in stress and resource supply associated with differences in emersion times. For example, organisms living higher on the shore experience drying, and extreme high and low temperatures that may physiologically stress their metabolisms more frequently and for longer periods than those lower on the 


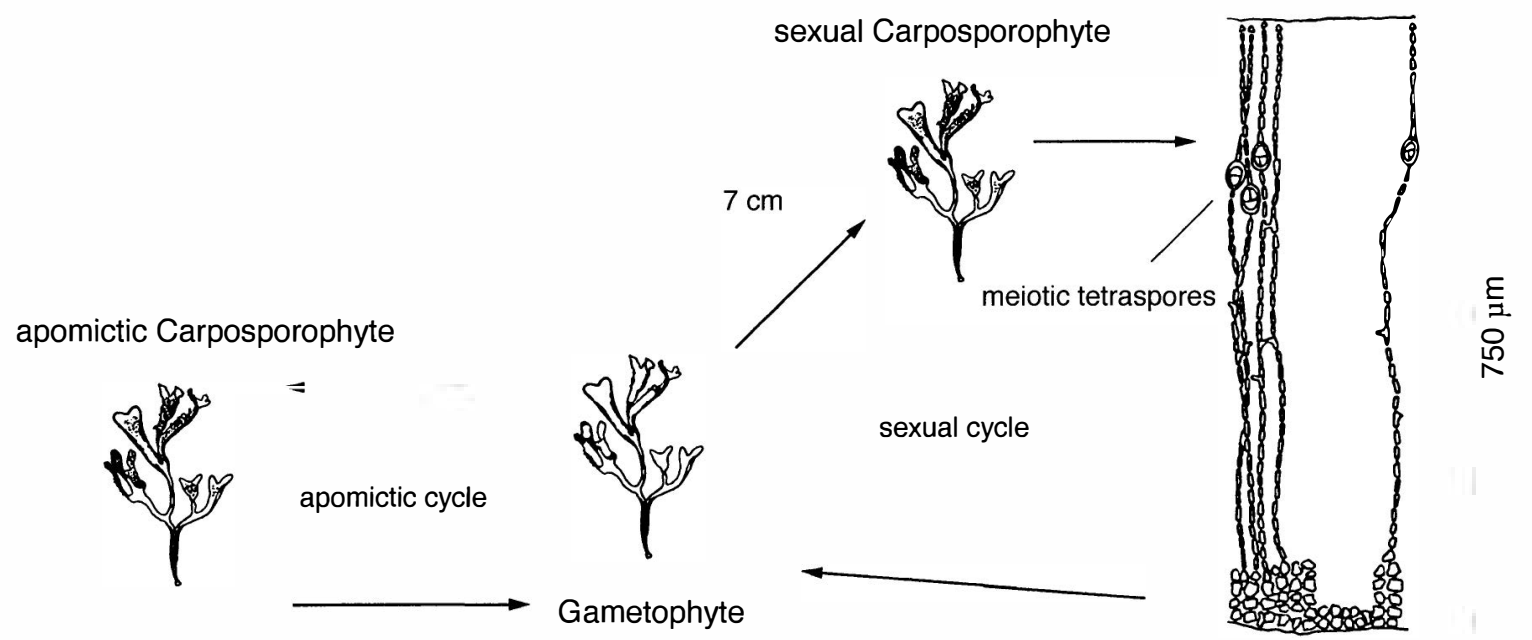

FIG. 1. Alternative life cycles in the life history of Mastocarpus stellatus. Sexual life cycle: Sexual upright gametophyte fronds following fertilization develop carpospores that settle and give rise to the crust phase (tetrasporophyte generation). For clarity, only a few of the filaments that comprise the upper part of the crust thallus are illustrated in the cross-section. Meiosis occurs in the formation of tetraspores in the crust phase, which generate upright gametophytes after settlement. Apomictic life cycle: Upright fronds produce carpospores without fertilization, which give rise to more apomitic upright fronds.

shore. More frequent and longer freezing exposures during winter low tides cause a greater proportion of C. crispus fronds high on the shore to bleach along their distal margins compared to fronds low on the shore (Dudgeon et al. 1990). Seaweeds high on the shore also have less time than those low on the shore to acquire resources (e.g., $\mathrm{HCO}_{3}^{-}, \mathrm{NO}_{3}^{-}$, or $\mathrm{NH}_{4}^{+}$, $\mathrm{PO}_{4}^{-}$) obtained from seawater. Similarly, the length of time that high shore habitats are submerged and, thus, can be supplied with propagules is less than low shore habitats. Consequently, the productivity of $C$. crispus or M. stellatus (or both) high on the shore may be less than that of conspecifics low on the shore.

Here we show in a moderately exposed rocky intertidal zone that (1) a competitive hierarchy exists among the upright fronds of two ecologically similar species, (2) the strength of competition among established fronds varies across environmental gradients of stress and resource supply, (3) the failure of upright fronds of $M$. stellatus to consistently recruit limits their abundance in the lowest zone and reduces preemptive competition, (4) these species coexist at the top end of the lower intertidal zone because this habitat limits the productivity of, and physiologically stresses, the dominant competitor, Chondrus crispus, and (5) coexistence at the lowest level of the intertidal zone is maintained in part by disturbances from winter storm waves that limit the abundance of $C$. crispus, and perhaps by organismal traits correlated with the crustose morphology of M. stellatus sporophytes. These results highlight three phenomena that are important in ecological communities. First, variation in the productivity of species in different environments, even at small spatial scales such as within the marine intertidal zone, mediates the strength of biotic interactions. Second, species often may not recruit within their realized (spatial) niche despite an abundant supply of propagules from the local population. And third, among species that mutually occupy a wide range of environments, different ecological processes may control coexistence of the same competitors in different places.

\section{Algal Natural History}

Chondrus crispus and Mastocarpus stellatus are close relatives (Guiry and Garbary 1990) and are the only species of their respective genera present in the north Atlantic Ocean (Lüning 1990). They differ principally in life history. The life history of $C$. crispus consists of an isomorphic alternation of generations. The morphology of both gametophytic and sporophytic generations is an upright frond with many branched, flattened, corticated blades supported by a narrow stipe (Algal Morphology Group Four sensu Steneck and Dethier 1994) that arises from a perennial basal disc holdfast. Upright fronds of M. stellatus (the male and female haploid gametophytes) show a remarkably similar anatomy and morphology to those of $C$. crispus. In contrast, the sporophyte generation of $M$. stellatus (also known as Petrocelis phase) is a thick $(\sim 750 \mu \mathrm{m})$, purplishred fleshy crust that adheres strongly to, and grows horizontally across, the substrate. In the sexual life history of M. stellatus, crustose diploid sporophytes are the product of fertilized spores released from female gametophytes (Fig. 1). Spores of the crusts (meiotic tetraspores) give rise to haploid male and female upright gametophytes. However, in Maine and many northerly populations, sexual gametophytes of $M$. stellatus rarely occur. Instead, apomixis (i.e., developing 
without a meiotic stage) predominates among upright fronds (West et al. 1977, Guiry and West 1983, Maggs 1988). These fronds produce carpospores that generate apomictic upright fronds instead of the alternate phase crust that occurs in the sexual life cycle. During 1990 and 1991, we found no sexual gametophytes from over 200 fronds sampled at Chamberlain and Pemaquid Point, Maine (S. R. Dudgeon, unpublished data). Hence, at our study sites upright fronds of $M$. stellatus can be produced from either tetraspores or apomictic carpospores.

The period of peak reproduction of both species is similar. Chondrus crispus reproduces at a low level throughout the year punctuated by a peak early in the fall (October; Mathieson and Prince 1973, Mathieson and Burns 1975). Mastocarpus stellatus reproduces in the fall and winter. Carpospores (either sexual or apomictic) mature in September and release thereafter through November, and tetraspores release from December through March (Burns and Mathieson 1972, S. $\mathrm{R}$. Dudgeon, personal observation). We note that the temporal window of most sporeling recruitment coincides with low abundances of amphipods, isopods, and herbivorous gastropods (see Results, also Vadas 1992). Nevertheless, fronds of both species primarily emerge from regenerating perennial holdfasts rather than from sporelings (Burns and Mathieson 1972, Mathieson and Burns 1975, Lubchenco 1980, Dudgeon et al. 1990).

\section{STudy Sites}

We conducted experiments at two locations $(\sim 8 \mathrm{~km}$ apart) in the Gulf of Maine, USA, Chamberlain (43.53' $\mathrm{N}, 69^{\circ} 28^{\prime} \mathrm{W}$ ) and Pemaquid Point, Maine $\left(43^{\circ} 50^{\prime} \mathrm{N}\right.$, $\left.69^{\circ} 31^{\prime} \mathrm{W}\right)$. Our study sites were at different places from the sites studied by Menge (1976), Lubchenco and Menge (1978), and Lubchenco (1980) at these same locations. The shoreline at Chamberlain (at Long Cove Point) is a moderate to steep sloping outcrop of primarily granitic and basaltic bedrock that shelters a cove on the west side from the waters of Muscongus Bay on the east. Most of the sloping bedrock along the peninsula and the east-facing shore northeast of the peninsula is dominated by red algae (primarily Chondrus on the cove side and Chondrus and Mastocarpus on the ocean side) low on the shore and three different species of Fucus (proceeding up the shore, F. evanescens, formerly $F$. distichus ssp. edentatus (Rice and Chapman 1985, Serraõ 1996), F. vesiculosus, and F. spiralis) and barnacles higher up. Near the proximal end of the peninsula is a boulder field protected from wave action that is dominated by the fucoid alga, Ascophyllum nodosum. These algal-dominated areas along the shoreline are interspersed by patches of mussels, ephemeral algae, and bare rock. Whereas at Chamberlain, Lubchenco and Menge worked on the cove side of the tip of the southward extending peninsula (B. Menge, personal communication), our sites were on the ocean side (facing east) $\sim 400-500$ m northeast of

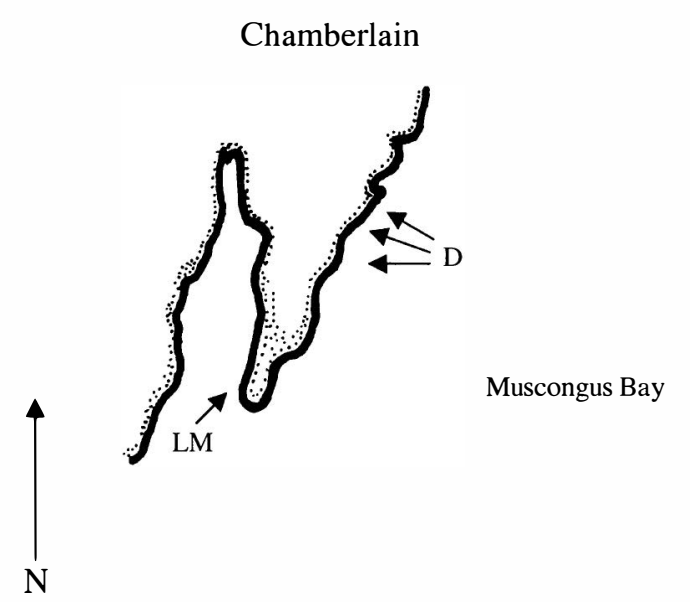

Pemaquid Point

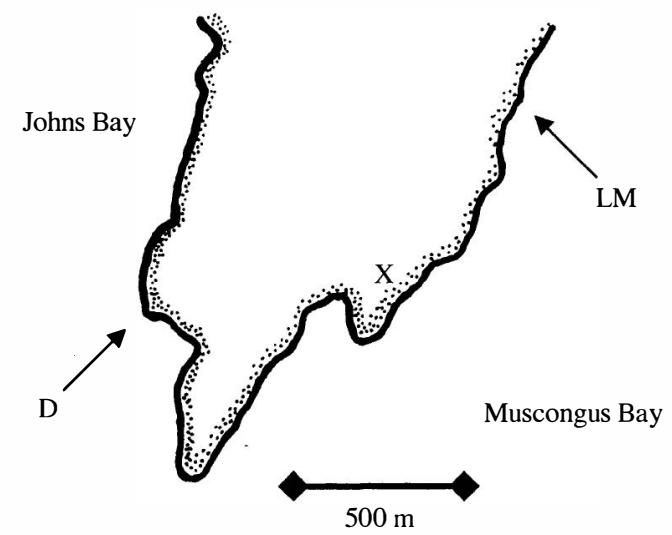

FIG. 2. Locations of study sites at (a) Chamberlain, Maine, and (b) Pemaquid Point, Maine. Locations denoted by a " $D$ " represent sites we used. Locations denoted "LM" represent sites used by Lubchenco and Menge. The " $X$ ", marks the location of the lighthouse at Pemaquid Point. The scale bar represents 500 meters.

the tip of the peninsula (Fig. 2a). The biota at each of these sites, together with wave force data taken independently at Chamberlain (G. Leonard, personal communication) suggest that most sites at Chamberlain, including those of Lubchenco and Menge and ours, are moderately exposed to wave action. Pemaquid Point is an outcropping of bedrock that protrudes southward from the coast into the Gulf of Maine and separates Johns Bay on the west from Muscongus Bay on the east. Our study sites at Pemaquid Point were on a southwest-facing rock outcrop on the Johns Bay side $\sim 500$ $\mathrm{m}$ northwest of the tip of the peninsula (Fig. 2b). The lower intertidal zone of this side of the peninsula is dominated by $C$. crispus and $M$. stellatus. Their dominance of the low zone extends both north of our sites and south to the tip of the peninsula and much of the way back up from the tip (towards the lighthouse) on the east side (S. R. Dudgeon and R. L. Vadas, personal observation, B. Menge, personal communication). The exposure along this stretch of shore varies from mod- 
Plate 1. The lower intertidal zone at Pemaquid Point, Maine in mid-March 1987. Tidal elevations increase from $\sim 0 \mathrm{~m}$ above MLW (far left) to $+1 \mathrm{~m}$ above MLW (far right). Patches of white are Chondrus crispus fronds that have bleached from repeated freezing exposure. Mastocarpus stellatus (interspersed gray areas) typically does not bleach.

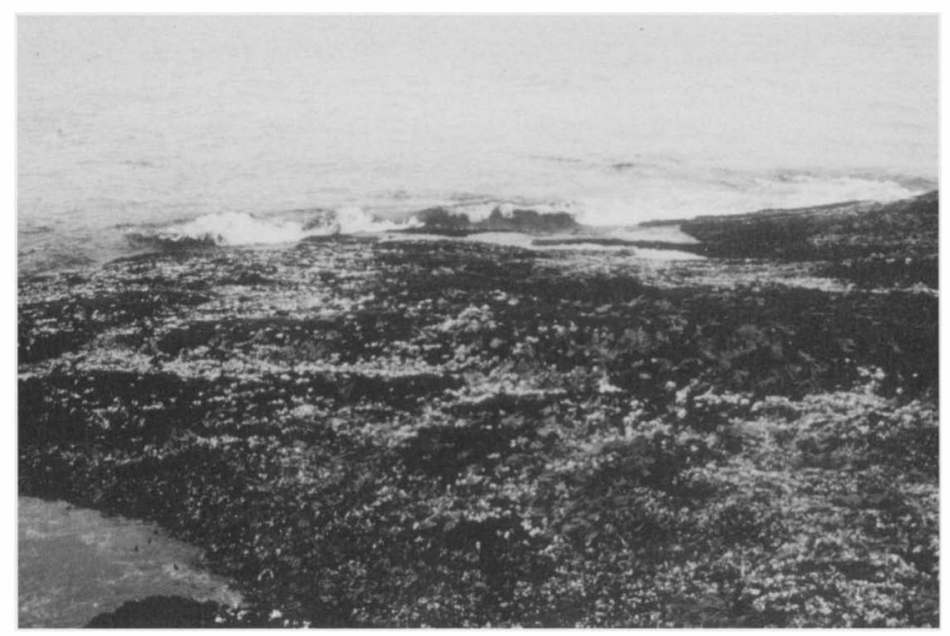

erate (at our sites) to extremely exposed at the tip where the maximum wave forces at this site have been recorded. (G. Leonard, personal communication). The site at Pemaquid Point studied by Lubchenco and Menge was a steeply sloping shore on the east (Muscongus Bay) side northeast of the tip of the peninsula that dropped off into deep water. This site was chosen by Lubchenco and Menge as potentially the most exposed stretch of shoreline, and was characterized by a high percent cover of Mytilus edulis (blue mussels) all the way down into the subtidal, some foliose red algae, and a canopy of the kelp Alaria esculenta during summer (B. Menge, personal communication). Distribution and abundance of $C$. crispus and $M$. stellatus were also observed at three other moderately exposed sites (north to south; Point LePreau, New Brunswick, Canada, $45^{\circ} 01^{\prime} \mathrm{N}, 66^{\circ} 27^{\prime} \mathrm{W}$; Schoodic Point, Maine, USA, $44^{\circ} 20^{\prime} \mathrm{N}, 68^{\circ} 03^{\prime} \mathrm{W}$; west-facing shores of the Isles of Shoals, New Hampshire and Maine, USA, 42 $58^{\prime} \mathrm{N}$, $70^{\circ} 37^{\prime} \mathrm{W}$ ) and two other exposed sites (north to south; east-facing shores of the Isles of Shoals; East Point, Nahant, Massachusetts, USA, $42^{\circ} 25^{\prime} \mathrm{N}, 70^{\circ} 55^{\prime} \mathrm{W}$ ) in the Gulf of Maine. The biota present at Chamberlain and Pemaquid Point are representative of that present at these other sites. Mobile consumers at these sites include several littorinids (Littorina spp.), whelks ( $\mathrm{Nu}$ cella lapillus), limpets (Tectura testudinalis), sea stars (Asterias vulgaris), and an assortment of isopods and amphipods (see Menge 1976, Lubchenco and Menge 1978, Hacker and Steneck 1990, and Vadas and Elner 1992 for complete descriptions). Sea urchins (Strongylocentrotus droebachiensis) rarely occur in the intertidal zone (Lubchenco 1978, Vadas and Elner 1992).

\section{Materials and Methods}

\section{Distribution and abundance patterns}

Seaweed spatial patterns.-We sampled surveyed bedrock stretches dominated by macroalgae between 0.0 and $+1.0 \mathrm{~m}$ above MLW (mean low water) at Chamberlain, Pemaquid Point (see Plate 1), and Sc- hoodic Point, Maine, to determine patterns of distribution and abundance of Chondrus crispus and Mastocarpus stellatus. We placed three spatially separated vertical transects ( $\sim 15-20 \mathrm{~m}$ long) along the shore that spanned representative portions of the low $(0.0$ to $+0.35 \mathrm{~m} \mathrm{MLW}$ ), mid-low ( +0.35 to $\sim 0.75 \mathrm{~m} \mathrm{MLW}$ ), and mid-high ( +0.75 to $+1.00 \mathrm{~m} \mathrm{MLW})$ intertidal zones (except for Schoodic Point where two transects were established). Data were collected from at least two randomly selected $20 \times 20 \mathrm{~cm}$ plots in each of the three zones for each transect. The percent cover of each species, both in the overstory and occupying primary substrate (following clipping of all erect thalli), was determined by photographing each plot twice (with and without canopy) using a camera (Kodak Ektachrome slide film) mounted on a quadrapod. We digitized (digitizing pad, HI PAD, Houston Instruments, Austin, Texas) areal coverage from outlines of each species on acetate sheets that were traced from the projected slides. In addition, we visually censused each plot in the field using a $20 \times 20 \mathrm{~cm}$ plexiglas quadrat containing 100 randomly distributed dots to compare with the photogrammetric method, and to identify species that may have been difficult to distinguish from a projected slide. Overall, our estimates of percent cover for the most common species were similar $( \pm 7 \%)$ using the two methods. The data presented in Table 1 represent those taken from photographs.

Temporal patterns of seaweed abundance.-We established five (six in the low zone less than $+0.35 \mathrm{~m}$ MLW) permanent quadrats each in the low, mid-low, and mid-high intertidal zones at Pemaquid Point corresponding to habitats dominated either by Chondrus crispus, a mixture of $C$. crispus and Mastocarpus stellatus, or M. stellatus. Our objective was to determine if patterns of distribution and abundance of either species in each zone, as represented by dry biomass, varied through time (e.g., seasonally, annually). The $20 \times 20$ $\mathrm{cm}$ plots were chosen haphazardly and marked at the corners with numbered tags embedded in Kopper's 
TABLE 1. Percent cover of Chondrus crispus, Mastocarpus stellatus, and associated species in the lower intertidal zone at three sites in the Gulf of Maine, USA.

\begin{tabular}{|c|c|c|c|c|c|c|c|c|c|}
\hline \multirow{2}{*}{$\begin{array}{l}\text { Tidal elevation } \\
\text { and species }\end{array}$} & \multicolumn{3}{|c|}{ Chamberlain } & \multicolumn{3}{|c|}{ Pemaquid Point } & \multicolumn{3}{|c|}{ Schoodic Point } \\
\hline & Overstory & Substrate & $N$ & Overstory & Substrate & $N$ & Overstory & Substrate & $N$ \\
\hline \multicolumn{10}{|c|}{ Mid-high $(+0.75$ to $+1.00 \mathrm{~m} \mathrm{MLW})$} \\
\hline $\begin{array}{l}\text { Chondrus crispus } \\
\text { Mastocarpus stellatus }\end{array}$ & $4.37(1.40)$ & $8.77(1.37)$ & 9 & $6.83(5.39)$ & $0.34(0.13)$ & 6 & $2.38(1.51)$ & $2.75(1.56)$ & 8 \\
\hline $\begin{array}{l}\text { Fronds } \\
\text { Crusts }\end{array}$ & $\begin{array}{c}55.26(10.43) \\
\ldots\end{array}$ & $\begin{array}{r}59.23(5.47) \\
2.73(0.99)\end{array}$ & $\begin{array}{l}9 \\
9\end{array}$ & $\begin{array}{c}41.00(14.57) \\
\ldots\end{array}$ & $\begin{array}{r}88.89(1.53) \\
0.91(0.32)\end{array}$ & $\begin{array}{l}6 \\
6\end{array}$ & $\begin{array}{c}15.63(8.40) \\
\ldots\end{array}$ & $\begin{array}{c}24.50(11.71) \\
0.00(0.00)\end{array}$ & $\begin{array}{l}8 \\
8\end{array}$ \\
\hline $\begin{array}{l}\text { Fucus vesiculosus } \\
\text { Fucus evanescens } \\
\text { Other perennial }\end{array}$ & $\begin{array}{c}32.42(12.87) \\
1.11(1.11)\end{array}$ & $\begin{array}{l}1.02(0.41) \\
0.00(0.00)\end{array}$ & $\begin{array}{l}9 \\
9\end{array}$ & $\begin{array}{c}41.67(17.76) \\
5.17(3.47)\end{array}$ & $\begin{array}{l}0.00(0.00) \\
0.00(0.00)\end{array}$ & $\begin{array}{l}6 \\
6\end{array}$ & $\begin{array}{r}29.75(10.84) \\
8.38(6.61)\end{array}$ & $\begin{array}{l}4.13(2.18) \\
2.38(1.77)\end{array}$ & $\begin{array}{l}8 \\
8\end{array}$ \\
\hline $\begin{array}{c}\text { algae } \\
\text { Ephemeral algae }\end{array}$ & $\begin{array}{l}0.44(0.44) \\
6.22(2.55)\end{array}$ & $\begin{array}{l}1.47(0.86) \\
3.33(1.26)\end{array}$ & $\begin{array}{l}9 \\
9\end{array}$ & $\begin{array}{l}0.33(0.33) \\
0.67(0.67)\end{array}$ & $\begin{array}{l}0.63(0.22) \\
2.42(0.41)\end{array}$ & $\begin{array}{l}6 \\
6\end{array}$ & $\begin{array}{r}23.63(7.20) \\
7.75(5.21)\end{array}$ & $\begin{array}{l}42.38(6.36) \\
10.38(6.80)\end{array}$ & $\begin{array}{l}8 \\
8\end{array}$ \\
\hline Mytilus edulis & $\ldots$ & $5.60(5.07)$ & 9 & $\ldots$ & $0.00(0.00)$ & 6 & $\ldots$ & $10.75(5.22)$ & 8 \\
\hline S. balanoides & $\cdots$ & $8.43(2.33)$ & 9 & $\cdots$ & $0.61(0.40)$ & 6 & $\cdots$ & $1.88(1.88)$ & 8 \\
\hline \multicolumn{10}{|c|}{ Mid-low $(+0.35$ to $+0.75 \mathrm{~m} \mathrm{MLW})$} \\
\hline $\begin{array}{l}\text { Chondrus crispus } \\
\text { Mastocarpus stellatus }\end{array}$ & $42.85(5.00)$ & $40.16(4.83)$ & 12 & $32.41(8.60)$ & $32.79(6.96)$ & 14 & $10.63(3.68)$ & $13.00(3.91)$ & 8 \\
\hline $\begin{array}{l}\text { Fronds } \\
\text { Crusts }\end{array}$ & $\begin{array}{c}46.08(0.08) \\
\ldots\end{array}$ & $\begin{array}{r}38.53(5.21) \\
7.42(1.62)\end{array}$ & $\begin{array}{l}12 \\
12\end{array}$ & $\begin{array}{c}40.59(7.65) \\
\ldots\end{array}$ & $\begin{array}{l}46.32(7.08) \\
11.53(2.81)\end{array}$ & $\begin{array}{l}14 \\
14\end{array}$ & $\begin{array}{c}52.38(5.20) \\
\ldots\end{array}$ & $\begin{array}{r}55.00(6.08) \\
4.00(2.93)\end{array}$ & $\begin{array}{l}8 \\
8\end{array}$ \\
\hline $\begin{array}{l}\text { Fucus vesiculosus } \\
\text { Fucus evanescens } \\
\text { Other perennial }\end{array}$ & $\begin{array}{l}0.58(0.58) \\
1.00(1.00)\end{array}$ & $\begin{array}{l}0.00(0.00) \\
0.00(0.00)\end{array}$ & $\begin{array}{l}12 \\
12\end{array}$ & $\begin{array}{r}19.50(8.27) \\
0.00(0.00)\end{array}$ & $\begin{array}{l}0.03(0.03) \\
0.00(0.00)\end{array}$ & $\begin{array}{l}14 \\
14\end{array}$ & $\begin{array}{l}3.75(1.50) \\
4.75(2.23)\end{array}$ & $\begin{array}{l}0.50(0.38) \\
0.00(0.00)\end{array}$ & $\begin{array}{l}8 \\
8\end{array}$ \\
\hline $\begin{array}{c}\text { algae } \\
\text { Ephemeral algae }\end{array}$ & $\begin{array}{l}0.75(0.58) \\
5.90(3.18)\end{array}$ & $\begin{array}{l}4.71(1.47) \\
1.90(0.58)\end{array}$ & $\begin{array}{l}12 \\
12\end{array}$ & $\begin{array}{l}0.14(0.14) \\
1.64(1.37)\end{array}$ & $\begin{array}{l}3.93(1.02) \\
0.31(0.16)\end{array}$ & $\begin{array}{l}14 \\
14\end{array}$ & $\begin{array}{r}23.75(5.92) \\
1.88(0.48)\end{array}$ & $\begin{array}{r}20.75(6.77) \\
3.75(2.77)\end{array}$ & $\begin{array}{l}8 \\
8\end{array}$ \\
\hline Mytilus edulis & ... & $1.08(0.63)$ & 12 & ... & $0.04(0.03)$ & 14 & 1.00 & $0.88(0.88)$ & 8 \\
\hline S. balanoides & $\cdots$ & $0.03(0.01)$ & 12 & $\cdots$ & $0.39(0.36)$ & 14 & $\cdots$ & $0.63(0.63)$ & 8 \\
\hline \multicolumn{10}{|c|}{ Low (less than or equal to $+0.35 \mathrm{~m}$ MLW) } \\
\hline $\begin{array}{l}\text { Chondrus crispus } \\
\text { Mastocarpus stellatus }\end{array}$ & $81.75(5.04)$ & $62.55(4.54)$ & 13 & $76.36(8.41)$ & $49.96(5.99)$ & 11 & $5.25(3.00)$ & $5.25(3.00)$ & 8 \\
\hline $\begin{array}{l}\text { Fronds } \\
\text { Crusts }\end{array}$ & $\begin{array}{c}0.10(0.10) \\
\ldots\end{array}$ & $\begin{array}{r}0.54(0.33) \\
26.14(5.28)\end{array}$ & $\begin{array}{l}13 \\
13\end{array}$ & $\begin{array}{c}1.09(1.09) \\
\ldots\end{array}$ & $\begin{array}{r}6.01(2.43) \\
32.37(6.06)\end{array}$ & $\begin{array}{l}11 \\
11\end{array}$ & $\begin{array}{c}34.25(8.98) \\
\ldots\end{array}$ & $\begin{array}{r}45.13(8.30) \\
5.88(3.98)\end{array}$ & $\begin{array}{l}8 \\
8\end{array}$ \\
\hline $\begin{array}{l}\text { Fucus vesiculosus } \\
\text { Fucus evanescens } \\
\text { Other perennial }\end{array}$ & $\begin{array}{l}0.00(0.00) \\
0.00(0.00)\end{array}$ & $\begin{array}{l}0.00(0.00) \\
0.14(0.14)\end{array}$ & $\begin{array}{l}13 \\
13\end{array}$ & $\begin{array}{l}0.00(0.00) \\
0.00(0.00)\end{array}$ & $\begin{array}{l}0.00(0.00) \\
0.00(0.00)\end{array}$ & $\begin{array}{l}11 \\
11\end{array}$ & $\begin{array}{l}3.50(2.29) \\
0.00(0.00)\end{array}$ & $\begin{array}{l}0.00(0.00) \\
0.00(0.00)\end{array}$ & $\begin{array}{l}8 \\
8\end{array}$ \\
\hline & & $3.98(1.38)$ & 13 & $22.27(8.44)$ & $9.99(1.28)$ & 11 & $50.00(7.34)$ & $26.00(5.10)$ & 8 \\
\hline Ephemeral algae & $4.38(3.68)$ & $1.67(0.74)$ & 13 & $0.27(0.27)$ & $0.12(0.08)$ & 11 & $1.13(0.88)$ & $1.63(0.92)$ & 8 \\
\hline Mytilus edulis & 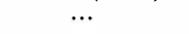 & $0.63(0.61)$ & 13 & $\ldots$ & $1.08(0.70)$ & 11 & $\ldots$ & $13.38(4.35)$ & 8 \\
\hline S. balanoides & $\ldots$ & $0.06(0.04)$ & 13 & $\ldots$ & $0.08(0.05)$ & 11 & $\cdots$ & $0.13(0.13)$ & 8 \\
\hline
\end{tabular}

Notes: $N=$ number of $20 \times 20 \mathrm{~cm}$ quadrats. Values represent mean percentages, with $1 \mathrm{SE}$ in parentheses. Data for Chamberlain and Pemaquid Point were collected in May 1989, and for Schoodic in September 1990.

Splash Zone Compound (Z-Spar, Kopper's Company, Incorporated, Los Angeles, California). Plots were sampled in 15 mo of a 21 -mo span (13 mo in the lowest zone due to heavy wave action).

We devised a method to estimate biomass of fronds of Chondrus crispus and Mastocarpus stellatus in plots nondestructively by sampling two parameters: the overstory percent cover (using the random dot plexiglas quadrat method) and the canopy height. For measures of canopy height a $20 \times 20 \mathrm{~cm}$ frame quadrat subdivided with string into sixteen $5 \times 5 \mathrm{~cm}$ squares was placed over the plot. The canopy height for the predominant species in each square was measured by inserting a ruler through the canopy to the substrate. The ruler was shaved to a narrow tip at one end so that it could be inserted through the algal canopy without disrupting the fronds. Based on the canopy height values in each square we calculated the mean canopy height for each species in the plot. We converted the mean canopy height into an estimate of dry biomass per 25 $\mathrm{cm}^{2}(5 \times 5 \mathrm{~cm})$ from linear regressions of dry biomass on canopy height for each species (Chondrus crispus, $y=0.439+0.427 x, r^{2}=0.79 ;$ Mastocar pus stellatus, $\left.y=-0.144+0.437 x, r^{2}=0.60\right)$. These values were expressed as biomass per $400 \mathrm{~cm}^{2}$ and then multiplied by the percent cover in the plot to arrive at the estimate of dry biomass.

Herbivore patterns. - To determine the potential for herbivorous gastropods (Littorina littorea, L. obtusata, Tectura testudinalis, Lacuna vincta) to govern the coexistence of Chondrus crispus and Mastocarpus stellatus, gastropod abundances were determined at 2- to 3-mo sampling intervals at Chamberlain and Pemaquid Point. Sampling consisted of two horizontal, $30 \mathrm{~m}$ long transects (spatially separated in series $\sim 10-15 \mathrm{~m}$ apart) placed parallel to the shoreline in both the low (less 
than $+0.35 \mathrm{~m} \mathrm{MLW}$ ) and mid-low/mid-high (greater than $+0.35 \mathrm{~m}$ MLW) tidal zones. In each of ten (weather permitting) randomly placed $20 \times 20 \mathrm{~cm}$ quadrats along each transect the species and length (greatest basal diameter, lip of the shell to the umbilicus) of each individual was recorded. We estimated the biomass of L. littorea and L. obtusata at each sampling from regressions of ash-free dry mass on basal diameter $(L$. littorea, $y=0.002 \times 10^{1.918 x}, r^{2}=0.86 ;$ L. obtusata, $\left.y=-0.01+0.082 x, r^{2}=0.76\right)$.

Several species of amphipods and isopods inhabit the seaweed canopy at these sites (Hacker and Steneck 1990). To quantify their potential to affect distribution limits of seaweeds, samples were collected from the low (less than $+0.35 \mathrm{~m} \mathrm{MLW}$ ) and mid-low/mid-high (greater than $+0.35 \mathrm{~m} \mathrm{MLW}$ ) tidal zones at Pemaquid Point in April, July, and October of 1989, but not during the winter months because neither amphipods nor isopods were observed in winter collections of macroalgae in three previous years. Samples were collected by placing a small plastic bag over a $25-\mathrm{cm}^{2}$ area to be harvested, sliding a paint scraper underneath to the substrate, and scraping all the organisms off the substrate into the bag and sealing it. Ten $5 \times 5 \mathrm{~cm}$ quadrats at tidal elevations both less than $+0.35 \mathrm{~m}$ and between +0.35 and $+1.00 \mathrm{~m}$ MLW were sampled in each month. Samples were returned to the laboratory, dried at $60^{\circ} \mathrm{C}$ for $48-72 \mathrm{~h}$, following which amphipods and isopods were removed from the dried sample, counted;' and weighed.

\section{Transplants of M. stellatus to the "Chondrus zone"}

A transplant experiment of upright fronds of Mastocarpus stellatus was performed at Pemaquid Point to determine if $M$. stellatus could survive in the " $C$. crispus-dominated" low zone. Fronds of $M$. stellatus were transplanted into cleared $20 \times 20 \mathrm{~cm}$ patches to two different tidal elevations in the "Chondrus zone" (0.0 $\mathrm{m}$ or $+0.20 \mathrm{~m} \mathrm{MLW})$ or back into their zone of collection (approximately $+1.5 \mathrm{~m} \mathrm{MLW)}$ to serve as controls. Nine replicates were used for each treatment. Replicates were pieces of rock overgrown with fronds of $M$. stellatus that were chipped from the intertidal zone with a hammer and chisel, embedded in plastic petri dishes with Z-Spar, and affixed to the shore with stainless steel screws secured in plastic anchors placed in holes drilled in the rock. Transplants were monitored monthly throughout the first 10 mo of the experiment and seasonally thereafter. Survivorship in the field was assessed in two ways. During the course of the experiment we observed whether upright fronds were present, were regenerating from holdfasts, or if absent, whether holdfasts retained their characteristic red color. After terminating the experiment, transplants with only holdfasts remaining were returned to the laboratory and cultured in seawater containing PES (Provasoli Enriched Seawater, Provasoli 1968) at 70-80 $\mu \mathrm{mol}$ photons $\cdot \mathrm{m}^{-2} \cdot \mathrm{s}^{-1}$ (16:8 light : dark cycle). The regeneration of upright fronds from these holdfasts was the criterion for survival and viability of the holdfast.

\section{Productivity gradient in the intertidal zone}

At Pemaquid Point we tested whether the production of biomass either by Chondrus crispus or Mastocarpus stellatus varied with tidal elevation by estimating the growth of regenerate fronds of each species at different heights in the intertidal zone. Plots $(20 \times 20 \mathrm{~cm})$ occupied exclusively by either $C$. crispus or $M$. stellatus were selected and marked at the corners with Z-Spar. All fronds were scraped away leaving only the holdfast covering the rock. Six replicate plots with $C$. crispus were established at each of three tidal elevations $(0.0$ $\mathrm{m},+0.25 \mathrm{~m}$, and $+0.5 \mathrm{~m} \mathrm{MLW})$ as were six replicate plots with $M$. stellatus at both $+0.5 \mathrm{~m}$ and $+0.75 \mathrm{~m}$ MLW. The experiment was initiated on 4 July 1989 and terminated on 13 November 1989. Regenerated upright fronds in each plot were harvested, dried at $60^{\circ} \mathrm{C}$ for $48 \mathrm{~h}$, and weighed. Only the central $10 \times 10 \mathrm{~cm}$ portion of each plot was harvested to minimize "edge effects" that can affect the growth of fronds along the margin of the plot.

Our measure of regenerate growth is a metric that combines both the density of regenerating fronds and per frond growth. Although this metric measures net regenerate growth of fronds, we believe that this design not only reflects the pattern of total growth, but can be used as a proxy for predicting patterns of net primary production per area as a function of tidal elevation in both species for the following reasons. First, neither species is readily consumed by herbivores that occur in the intertidal zone (Lubchenco 1978, see Results: Consumption of red algae). Second, all fronds regenerated from holdfasts and, hence, were of small to moderate size. Since only large fronds are readily dislodged by waves (Dudgeon and Johnson 1992) and the experiment was conducted between July and early November when storm waves rarely occur, the loss of biomass due to wave action was minimal. Therefore, two principal sources that remove biomass from algal populations were not important during the period of this experiment and, hence, net regenerate growth reasonably approximates total regenerate growth. Our assertion that in situ estimates of growth of these species at different tidal elevations can serve as proxies for their patterns of primary production is based on laboratory experiments on both species demonstrating that photosynthesis and growth respond similarly across a range of conditions (e.g., different exposure times to freezing or desiccation) representative of those occurring at different tidal elevations (Davison et al. 1989, Dudgeon et al. 1989, 1990, 1995).

\section{Species mixture at two tidal heights: effects on growth}

A substitutive experimental design (de Wit 1960) was used to test if the growth of either Chondrus cris- 
pus or Mastocarpus stellatus in mixed stands at different tidal levels was influenced by the presence of the other species. The density of stipes $\left(2.987 \times 10^{4}\right.$ stipes $/ \mathrm{m}^{2}$ ) used in the experiment was based on measurements of density in fifteen $5 \times 5 \mathrm{~cm}$ quadrats containing at least one of the species in the low and midlow zones. A linear regression analysis of biomass on stipe density of 10 quadrats $(5 \times 5 \mathrm{~cm})$ with $C$. crispus only and 10 containing only $M$. stellatus that ranged from $\sim 5 \times 10^{3}$ to $3.5 \times 10^{4}$ stipes $/ \mathrm{m}^{2}$ satisfied the assumption of a linear response of biomass as a function of density (i.e., in a range of densities less than that where intraspecific competition occurs) for both species (C. crispus, $r^{2}=0.78 ; M$. stellatus, $r^{2}=0.73$ ) that is inherent in replacement series experimental designs and is necessary to distinguish among the possible outcomes of the experiment. For either species the possible outcomes of the experiment are that the presence of the other species has no effect (i.e., biomass at a given density in a species mixture is not different from that predicted by the linear isocline for growth in pure stands $\left[\alpha_{i j}\right.$ is zero]), a positive effect (i.e., biomass in mixture is greater than that predicted by the isocline $\left[\alpha_{i j}<0\right]$ ), or a negative (competitive) effect (i.e., biomass in mixture is less than that predicted by the isocline $\left.\left[\alpha_{i j}>0\right]\right)$.

Pieces of rock containing stipes of either Chondrus crispus or Mastocarpus stellatus were chiseled from the shore (approximately +0.2 to $+0.5 \mathrm{~m} \mathrm{MLW)} \mathrm{with}$ a hammer, returned to the laboratory and maintained in flowing seawater tables at $\sim 150$ to $200 \mu \mathrm{mol}$ photons $\cdot \mathrm{m}^{-2} \cdot \mathrm{s}^{-1}$ and ambient seawater temperatures $\left(12^{\circ}\right.$ to $15^{\circ} \mathrm{C}$ ) until the experiment was deployed ( $\left.\sim 2 \mathrm{wk}\right)$. The pieces of rock were cut with wire cutters in order to fit several rocks together as an experimental unit. Rocks were embedded in $100 \times 15 \mathrm{~mm}$ plastic petri dishes containing Z-Spar at a total stipe density of $2.987 \times$ $10^{4} \mathrm{stipes} / \mathrm{m}^{2}$. Three treatments were established: $100 \%$ C. crispus, $0 \%$ M. stellatus; $50 \%$ C. crispus, $50 \%$ M. stellatus; $0 \%$ C. crispus, $100 \%$ M. stellatus. In the 50:50 treatment the stipes of each species were placed in an alternating arrangement in the dish. Since broken stipe of both species can regenerate (S. R. Dudgeon, personal observation), all fronds were clipped at the stipe $1 \mathrm{~cm}$ above the holdfast so that no advantage would be conferred to larger fronds. Experimental dishes were affixed to the shore with stainless steel screws secured into plastic anchors placed in holes drilled in the rock. Five replicates of each of the three treatments were established in both the low $(\sim 0.0 \mathrm{~m} \mathrm{MLW})$ and mid-low (approximately $+0.5 \mathrm{~m}$ MLW) intertidal zones at Pemaquid Point. The experiment was initiated 4 July 1989 and terminated in August 1990.

Since this experiment tests overgrowth of fronds as a mechanism of competition, the response variables were the biomass yield (final mass minus the quantity of estimated initial mass of a $1.0-\mathrm{cm}$ stipe [determined from the mean mass of ten $1.0 \mathrm{~cm}$ long stipes for each species] multiplied by the density of stipes) of both species and the number of papillae (reproductive structures) on Mastocarpus stellatus fronds. Mann-Whitney $U$ tests comparing the observed yield, or papillae density, in the 50:50 mixture with the predicted values for that treatment were used for tests of significance. Since the intraspecific response to density was shown above to be linear, the expected mean and variance of the isocline at the 50:50 mixture point was determined from a sample obtained by dividing yield or papillae density of each replicate in the $100 \%$ treatment by two.

\section{Mastocarpus recruitment and regeneration: effects of competitors and herbivorous gastropods}

To determine whether upright fronds of Mastocarpus stellatus in the low intertidal zone compete interspecifically with Chondrus crispus, intraspecifically with crusts, or are consumed by herbivorous gastropods, we initiated a "deletion" experiment at Chamberlain. This experiment was established in the low intertidal zone in late August 1988 prior to the peak reproductive period of both apomictic (September through November) and crustose (December through March) thalli of $M$. stellatus (Burns and Mathieson 1972, S. R. Dudgeon, unpublished data) and was terminated in September 1990. The size of each plot was $25 \times 25 \mathrm{~cm}$. In each experimental plot $C$. crispus initially covered $\geq 95 \%$ of the overstory (canopy) level. There were three levels of each treatment. Levels of the $C$. crispus deletion treatment consisted of unmanipulated controls, frond only removal (leaving the encrusting holdfast and crusts of $M$. stellatus intact), and total removal (fronds and holdfasts of $C$. crispus, and crusts of M. stellatus, removed by scraping away all noncrustose organisms followed by burning the substrate of a plot for several minutes with a propane torch). Levels of the herbivore exclusion treatment consisted of full $20 \times 20 \times 5 \mathrm{~cm}$ stainless steel mesh cages (mesh size $=3.2 \mathrm{~mm}$ ) centrally placed within the $25 \times 25 \mathrm{~cm}$ plots and both sideless "roof" cages (also $20 \times 20 \times 5 \mathrm{~cm}$ ) and open, uncaged $(25 \times 25 \mathrm{~cm})$ plots for evaluating artifacts associated with the presence of the cage (Connell 1961, Dayton 1971, Chapman 1989). Data were collected only from the central $20 \times 20 \mathrm{~cm}$ region of the uncaged plots. Caged plots were monitored monthly in the winter and every 2-3 wk in spring and summer to remove any herbivorous gastropods that entered, or ephemeral algae on the cage, or debris (shell grit) that accumulated in the cage. No attempts were made to control in experimental plots the number of dogwhelks (Nucella lapillus), which were common at Chamberlain or sea stars (Asterias spp.), which were uncommon.

An orthogonal, randomized block design enabled all combinations of treatment levels to be represented in each block. Therefore, each block consisted of nine plots. Because of the topographical heterogeneity of the shore at Chamberlain, the three full cage treatments in each block were systematically assigned to the three 
plots providing the most satisfactory fit between the stainless steel mesh cage girdle and the substrate. However, the levels of the "Chondrus removal" treatment were randomly assigned to the three caged plots. The six remaining treatment combinations were randomly assigned to the six remaining plots in a block. The nine plots within a block were staggered along the shoreline and spread approximately evenly over a distance of $\sim 12 \mathrm{~m}$. Three spatially separated replicate blocks were established across $>100 \mathrm{~m}$ of the shoreline at Chamberlain. In addition, five $20 \times 20 \mathrm{~cm}$ total removal plots were established in the mid-high zone to assess recruitment of Mastocarpus to habitats where upright fronds of Mastocarpus dominate space.

Data were collected following 3, 6, 8, 11, 20, and $24 \mathrm{mo}$. The data from month 24 were used for statistical analysis (except for that of Fucus recruitment where the data of August 1989 were analyzed). Plots were photographed and percent cover determined as described (Results: Distribution and abundance, Seaweed spatial patterns). In addition, each plot was visually censused with a $20 \times 20 \mathrm{~cm}$ plexiglas quadrat containing 100 randomly distributed dots. Percent cover data for Chondrus crispus and upright fronds of Mastocarpus stellatus reflect their overstory abundance, whereas data for crusts of $M$. stellatus reflect percent cover of primary substrate. Successful recruitment in this study was defined as a thallus (holdfast and/or upright frond) visible to the unaided eye occurring in a total removal plot. The presence of fronds over time in "frond removal" plots was attributed to regeneration from holdfasts rather than from recruitment by sporelings.

An inherent problem with randomized block experimental designs is the lack of replication of treatments within blocks preventing an estimate of the residual mean square (Underwood 1981). Consequently, the inability to detect interactions among treatments because no treatment interactions are assumed (i.e., assuming the treatment effects are additive), confounds hypotheses about main treatment effects. Tukey's test for nonadditivity was used to test the assumption that treatment effects operate independently of one another. The sum of squares for nonadditivity was subtracted from the three-way interaction sum of squares leaving a remainder. The $F$ ratio $(\mathrm{df}=1,[a-1][b-1][c-1]$ - 1) of these mean square estimates was the test for additivity. Subsequently, $F$ ratios for two-factor interaction terms were constructed using the three-way interaction term as the residual mean square. Nonsignificant interaction terms were examined for post hoc pooling at $(\alpha=0.25)$ as described by Winer (1971). The significance of treatment effects on the abundance of Mastocarpus stellatus was estimated using a threefactor ANOVA with the post hoc pooled interaction term to estimate the residual mean square. The detection of artifacts was examined by comparing the abun- dances of Chondrus crispus, M. stellatus, and herbivorous gastropods in all roof vs. "open" plots.

\section{Laboratory food preference experiments}

Fronds of each species for all feeding experiments were collected from Chamberlain, transported to the laboratory in seawater, cleaned of visible epibionts, and maintained in plexiglas aquaria containing $6 \mathrm{~L}$ of aerated, filtered (Whatman glass fiber filter circles [Whatman Incorporated, Clifton, New Jersey]) Provasoli-enriched seawater (PES) at $15^{\circ} \mathrm{C}$ and at $70-80 \mu \mathrm{mol}$ photons $\cdot \mathrm{m}^{-2} \cdot \mathrm{s}^{-1}$ on a $16: 8$ light : dark cycle until used. Littorina littorea or L. obtusata (depending on the experiment) were also collected at Chamberlain, returned to the laboratory in a container without macroalgae, and maintained in aquaria containing $6 \mathrm{~L}$ of aerated, filtered seawater at $15^{\circ} \mathrm{C}$ and no food for 48 $\mathrm{h}$ prior to experimental treatments.

Four liter plexiglas pots, divided into two equal-sized compartments by a $1.0-\mathrm{mm}$ nylon mesh screen (preventing snails from moving between the two sides of the tank), containing PES-enriched, aerated seawater were used for feeding experiments. One side contained algae and littorinids, the other side only algae. Thus, control and experimental treatments were performed in the same pot. This design assured that control and experimental seaweeds experienced identical nutrient regimes (PES enrichment plus that of nutrients released into seawater by the snails). Feeding experiments were conducted at $15^{\circ} \mathrm{C}$ and at $70-80 \mu \mathrm{mol}$ photons $\cdot \mathrm{m}^{-2} \cdot \mathrm{s}^{-1}$ on a 16:8 light: dark cycle.

The following measures were made to determine the algal biomass consumed by herbivores. Initial dry: wet mass ratios of algae were determined from four replicates of each species prior to each experiment by weighing samples before and after drying $24 \mathrm{~h}$ in a $60^{\circ} \mathrm{C}$ oven. The fresh mass of fronds was determined by blotting away excess surface water with a paper towel prior to weighing. Following each experiment the dry masses, as well as fresh masses, of control and experimental fronds were determined. Dry mass of algae lost due to grazing in feeding experiments was estimated by adding the dry mass growth of controls from the same pot to the initial dry mass estimate of experimental fronds and subtracting the final dry mass of the experimental fronds. Snails were dried for $72 \mathrm{~h}$ at $60^{\circ} \mathrm{C}$, after which their organic dry masses were estimated following combustion in a muffle furnace for $24 \mathrm{~h}$ at $550^{\circ} \mathrm{C}$. Consumption rates were estimated as the algal mass lost due to grazing per gram ash-free dry mass of snail per hour (see Peterson and Renaud 1989, for a discussion of the assumptions involved in such estimates).

Single choice assay.- Three species of macroalgae, Chondrus crispus, Mastocarpus stellatus, and Porphyra spp. were offered in single choice feeding assays to either Littorina littorea or L. obtusata. Porphyra spp. are ephemeral algae, which are generally thought to be preferred prey of herbivorous gastropods (Lubchenco 
1978) and therefore serve as a reference to compare with consumption of $C$. crispus and $M$. stellatus. In each of four replicate pots for each species, $2 \pm 0.5 \mathrm{~g}$ fresh mass of algae were placed in both the "herbivore present" and "herbivore absent" compartments. Twenty-five snails (either L. littorea or L. obtusata) were added to the herbivore present compartment. Singlechoice feeding experiments lasted $3 \mathrm{~d}$.

Comparisons were made of changes in algal mass of control (no herbivores) and experimental (herbivores present) treatments between pairs of species to determine if either species of Littorina exhibited preferences between algal foods. The interaction term from three $2 \times 2$ ANOVA (factor 1: species, three pairs; Chondrus crispus vs. Mastocarpus stellatus, C. crispus vs. Porphyra spp., M. stellatus vs. Porphyra spp.; factor 2: herbivore vs. control treatment) of the log-transformed data was used to test for significant preference (Peterson and Renaud 1989).

Multiple choice assay.-Chondrus crispus and Mastocarpus stellatus were offered together to Littorina littorea in a multiple choice feeding assay. Both compartments of each of 12 replicate pots contained $4 \pm$ $0.25 \mathrm{~g}$ fresh mass of each species. Twenty-five L. littorea were added to one compartment of each pot. The experiment was conducted for $2 \mathrm{wk}$ during which the seawater was changed every 4-5 d.

For each replicate pot, the difference in change in mass between species was calculated for each treatment. The two sets of differences (experimentals and controls) were compared using the Mann-Whitney $U$ test to determine if one species was preferentially consumed (Peterson and Renaud 1989).

\section{RESUlts}

\section{Spatial and temporal patterns of Chondrus and Mastocarpus}

The distribution and abundance of Chondrus crispus and Mastocarpus stellatus at both Chamberlain and Pemaquid Point are representative of many moderate to relatively exposed sites in the Gulf of Maine, including among others Pt. LePreau, the Isles of Shoals, and East Point at Nahant. These two species co-occur throughout the 0.0 to $+1.0 \mathrm{~m}$ above MLW tidal range in three distinct zones (Table 1). The lowest zone is dominated by $C$. crispus. Upright fronds of $M$. stellatus rarely occur below $+0.35 \mathrm{~m} \mathrm{MLW}$; however, crusts of $M$. stellatus occupy much of this zone. Higher on the shore, in the mid-low zone, $C$. crispus and $M$. stellatus form an evenly mixed stand. The abundance of $C$. crispus declines further above $+0.75 \mathrm{~m}$ MLW where upright fronds of $M$. stellatus predominate under a canopy of mostly Fucus vesiculosus. Crusts of $M$. stellatus also decline in abundance with increasing tidal elevation resulting in a spatial separation of upright and crustose life history phases on the shore; crusts are abundant

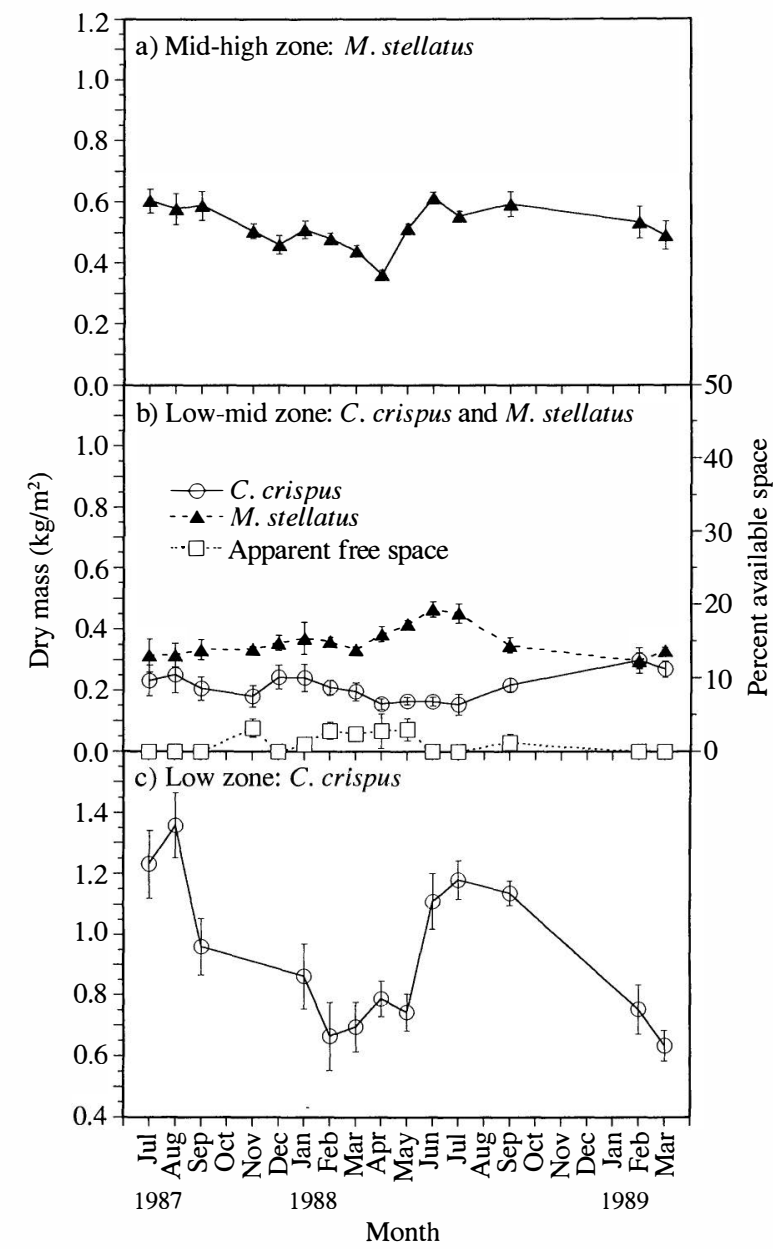

FIG. 3. Temporal variation in dry biomass over a 21-mo period at Pemaquid Point in (a) the mid-high zone dominated by $M$. stellatus, (b) the mid-low zone where $C$. crispus and Mastocarpus stellatus coexist, and (c) the low zone dominated by Chondrus crispus. Percent cover of apparent available space is shown for the mid-low zone (b) where the two species coexist in similar abundance. Values represent mean $\pm 1 \mathrm{SE}$ of $N=5$ plots ( 6 in the low zone).

low on the shore, whereas upright fronds are abundant higher on the shore.

An exception to this pattern occurs at Schoodic Point. At this site, Chondrus crispus and crusts of Mastocarpus stellatus occur infrequently in the lower intertidal zone. In their absence, upright fronds of $M$. stellatus, other perennial algae, and mussels occupy much of the overstory and substrate levels. As at other sites, M. stellatus is a dominant space occupier in the mid-low and mid-high zones.

The temporal patterns of biomass of Chondrus crispus differ between fronds living in the low zone and those living higher on the shore (Fig. 3). C. crispus living in the low zone showed large fluctuations in biomass over the 2 -yr period of monitoring, characterized by peaks in biomass late in summer, and minima 


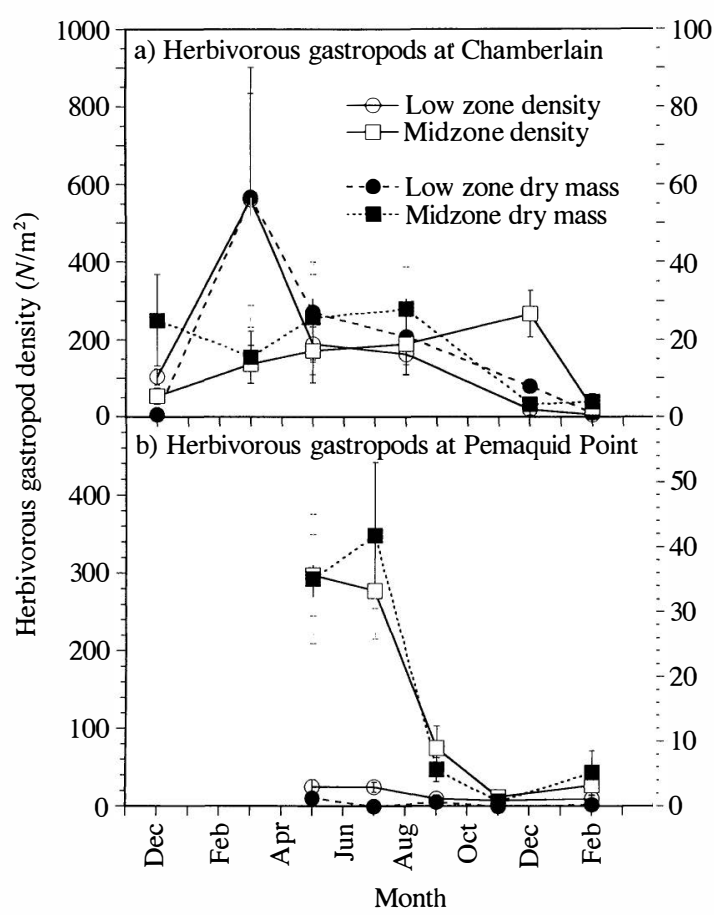

FIG. 4. Variation in density of all herbivorous gastropods, and ash-free dry mass of littorinids, at (a) Chamberlain, Maine, during 1989 and (b) Pemaquid Point during 1988, in both the midzone (greater than $+0.35 \mathrm{~m}$ MLW) and low zone (less than $+0.35 \mathrm{~m} \mathrm{MLW}$ ). Values represent mean $\pm 1 \mathrm{sE}$ of $N \geq 6,20 \times 20 \mathrm{~cm}$ quadrats in each zone in each month.

in winter. In contrast, the biomass of $C$. crispus fronds higher on the shore was much less, and remained at roughly constant levels over 2 yr. Mastocarpus stellatus in the mid-low and mid-high intertidal zones showed little annual fluctuations in biomass. The combined biomass of the two species in the mid-low zone, where upright fronds of the two species coexist in similar abundance, is similar to that of $M$. stellatus alone in the mid-high zone. In the mid-low (mixed) zone there was never $>3 \%$ apparent free space (i.e., rock; Fig. $3 b)$.

\section{Spatial and temporal patterns of herbivores}

The abundance of herbivorous gastropods varied considerably in both space and time at Chamberlain and Pemaquid Point (Fig. 4). The trends of littorinid biomass at both sites parallel the pattern of total herbivorous gastropod density. On average, littorinids (here, Littorina littorea and L. obtusata) accounted for 72 and $92 \%$ at Pemaquid Point and Chamberlain, respectively, of all herbivorous gastropods sampled each month (data not shown). Grazer densities were generally greater throughout the year at Chamberlain than at Pemaquid Point, with no distinct pattern emerging during the period sampled (but see Vadas 1992) at the former site between tidal heights less than $+0.35 \mathrm{~m}$ and those greater than +0.35 (up to +1.00 ) $\mathrm{m} \mathrm{MLW}$.

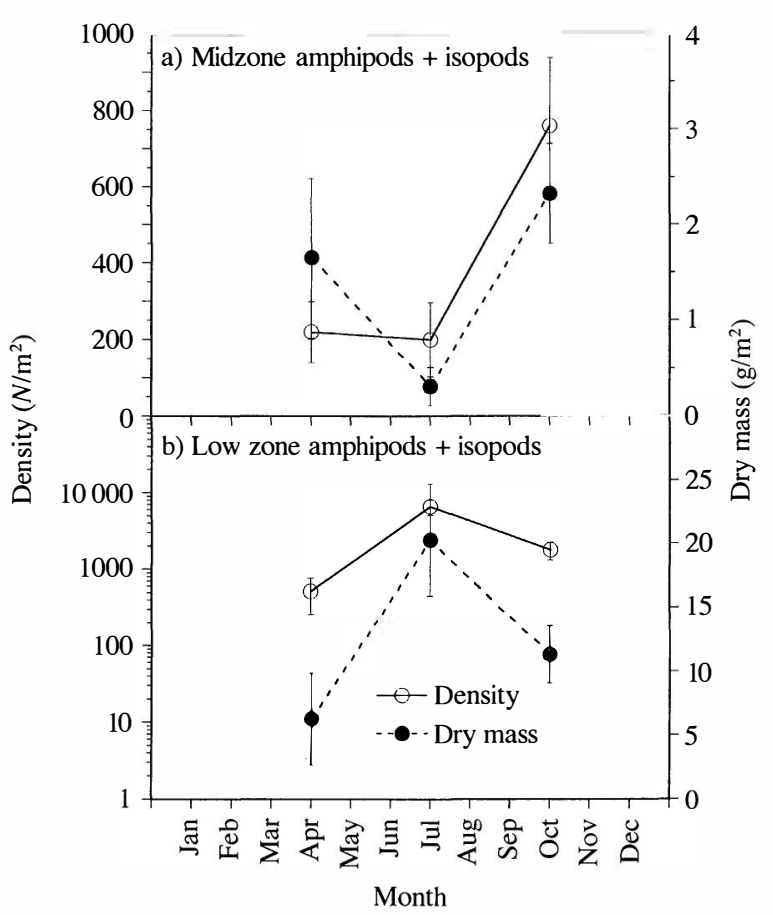

FIG. 5. Variation in density and dry mass of amphipod and isopod species at Pemaquid Point in the spring, summer, and fall of 1988 in (a) the midzone (greater than $+0.35 \mathrm{~m}$ MLW) and (b) the low zone (less than $+0.35 \mathrm{~m}$ MLW). Values represent mean $\pm 1 \mathrm{SE}$ of $N=10,5 \times 5 \mathrm{~cm}$ quadrats in each zone in each month.

Few gastropods were observed in the low zone at Pemaquid Point in any month. In contrast, a distinct pattern of herbivorous gastropod abundance at tidal elevations between +0.35 and +1.00 m MLW comprised by a spring maximum and winter minimum was evident at this site.

The abundances of amphipods and isopods at Pemaquid Point fluctuated dramatically throughout the sampling period (Fig. 5). The peak abundance in the low zone (less than +0.35 m MLW) occurred in July, largely reflecting the recent recruitment of juvenile gammaridean amphipods. Densities of amphipods and isopods at tidal elevations between +0.35 and +1.00 $\mathrm{m}$ MLW were far less than in the low zone, but also fluctuated throughout the year. The greatest abundance at these elevations occurred early in the fall and was comprised primarily of juvenile isopods.

It is noteworthy that the periods of peak abundance (and activity) of herbivores, hence, the potential for them to cause disturbance, is greater in spring, summer, and fall than in winter, coinciding with the peaks in biomass of Chondrus crispus and Mastocarpus stellatus.

\section{Transplants of Mastocarpus}

Transplants of Mastocarpus stellatus indicated that upright fronds can persist in the low zone beyond their 


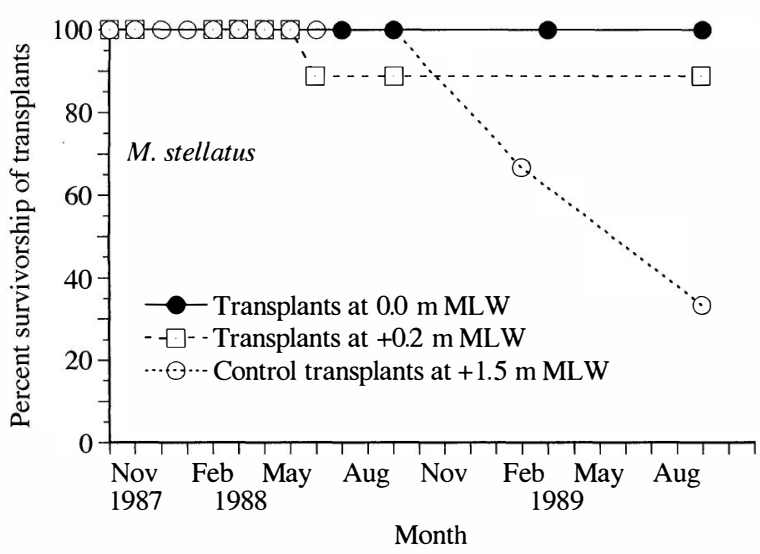

FIG. 6. Survivorship at Pemaquid Point of Mastocarpus stellatus transplanted to cleared patches in the "Mastocarpus zone" $(+1.5 \mathrm{~m} \mathrm{MLW})$ to serve as controls $(\bigcirc)$, the "Chondrus zone" at approximately $+0.20 \mathrm{~m} \mathrm{MLW} \mathrm{( \square ),} \mathrm{or} \mathrm{"Chon-}$ drus zone" at $0.0 \mathrm{~m} \mathrm{MLW} \mathrm{(O).} \mathrm{Nine} \mathrm{replicates} \mathrm{were} \mathrm{moni-}$ tored over time at each tidal elevation.

typical intertidal distribution. $M$. stellatus transplanted into cleared patches in the "Chondrus zone" survived 2 yr (Fig. 6) and all survivors but one exhibited upright fronds when the experiment was terminated. In fact, low zone transplants survived better than controls transplanted back into the Mastocarpus zone.

\section{Productivity gradient in the intertidal zone}

The net dry mass of Chondrus crispus produced per unit area during the summer-fall growing season varied with tidal elevation (Fig. 7). Single degree of freedom orthogonal contrasts indicated that the decline in production of biomass of $C$. crispus with increasing tidal elevation followed a nonlinear function (linear contrast, $F_{1,15}=1.38, P>0.25$, power $=(1-\beta)=0.26$, noncentrality parameter $=\phi=0.81$; quadratic contrast $\left.F_{1,15}=47.23, P<0.01\right)$. The greatest step in declining production occurred between $C$. crispus at mean low water and those at $+0.25 \mathrm{~m} \mathrm{MLW}\left(F_{1,15}=28.78, P<\right.$ $0.01)$, but there was no significant difference between fronds at +0.25 and $+0.5 \mathrm{~m} \mathrm{MLW}\left(F_{1,15}=1.38, P>\right.$ $0.25,(1-\beta)=0.37, \phi=1.00)$. However, the power of these tests was weak. Upright fronds of Mastocarpus stellatus also showed no significant difference in the biomass produced at $+0.5 \mathrm{~m}$ from that at $+0.75 \mathrm{~m}$ MLW (Fig. 7; $F_{1,10}=0.44, P>0.50,(1-\beta)=0.90$, $\phi=2.56)$. Moreover, the power of the test to detect differences in the growth of $M$. stellatus was great. Power analyses were based on the assumption that a difference in biomass production of $1.0 \mathrm{~g}$ dry mass $\cdot \mathrm{m}^{-2} \cdot \mathrm{d}$ between fronds at different tidal heights (or between species at the same tidal height as below) was the minimum biologically significant effect size.

A comparison of the quantity of biomass produced at $+0.5 \mathrm{~m}$ MLW by Chondrus crispus and Mastocarpus stellatus also showed no significant difference, but

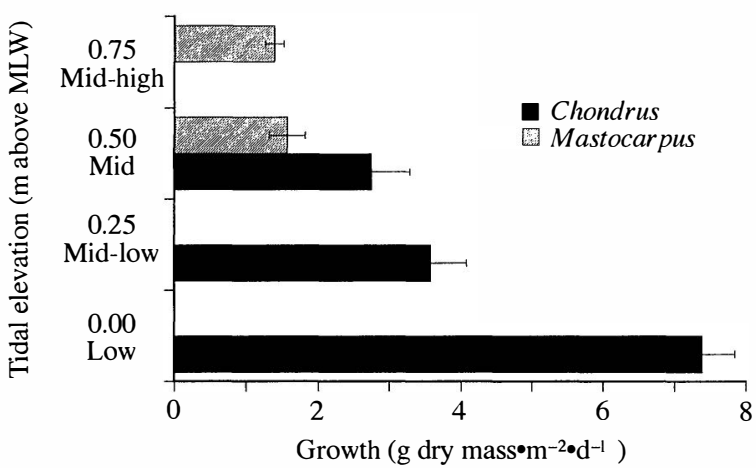

FIg. 7. Net growth of fronds of Chondrus crispus and Mastocarpus stellatus at Pemaquid Point as a function of tidal elevation. Values represent the mean \pm 1 SE of $N=6$ replicates for each species at each tidal elevation.

again the power of the test was weak $\left(F_{1,10}=3.99, P\right.$ $>0.05,(1-\beta)=0.33, \phi=1.20)$.

\section{Competition among established mixed stands of Chondrus and Mastocarpus}

The net yield of Mastocarpus stellatus was depressed significantly below the predicted yield when grown in the low zone in a 50:50 mixture with Chondrus crispus (Fig. 8; $U=20, n=4, m=5, P<0.05$ ). Moreover, M. stellatus produced fewer reproductive papillae than that predicted for that density of fronds when grown in mixture with $C$. crispus (Fig. 9; $U=19, n=4, m$ $=5, P<0.05)$. Therefore, the presence of $C$. crispus in mixed stands negatively affected the growth and potential reproductive output of $M$. stellatus in the low zone.

In contrast to the low zone, the yield in the mid-low zone of neither species differed significantly from their respective predicted yields in a 50:50 mixture (Fig. 10; C. crispus, $U=17, n=m=5, P>0.20 ; M$. stellatus, $U=17, n=m=5, P>0.20)$. This outcome indicates

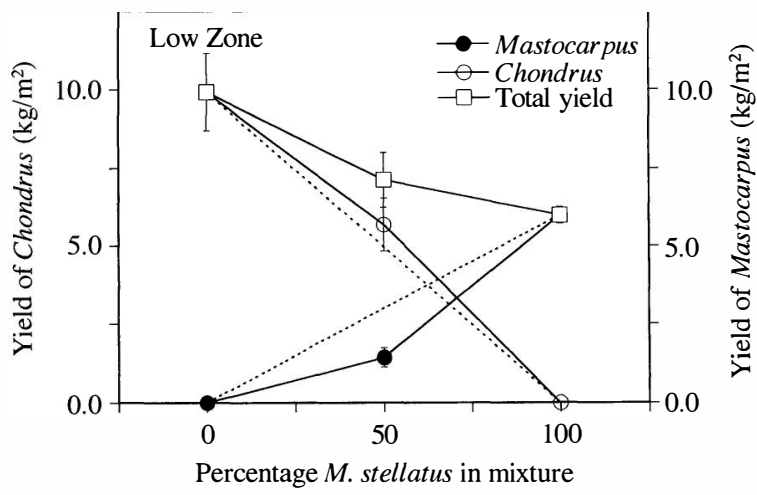

FIG. 8. Fresh mass yield of Chondrus crispus and Mastocarpus stellatus growing either alone or in a 50:50 mixture in the low zone at Pemaquid Point, Maine. Squares represent the combined yield of both species for each mixture. Dashed lines represent the predicted yields of each species in the absence of the other. Values represent means $\pm 1 \mathrm{SE}$ of $N=$ 4 (except for the 50:50 mixture, where $N=5$ ). 


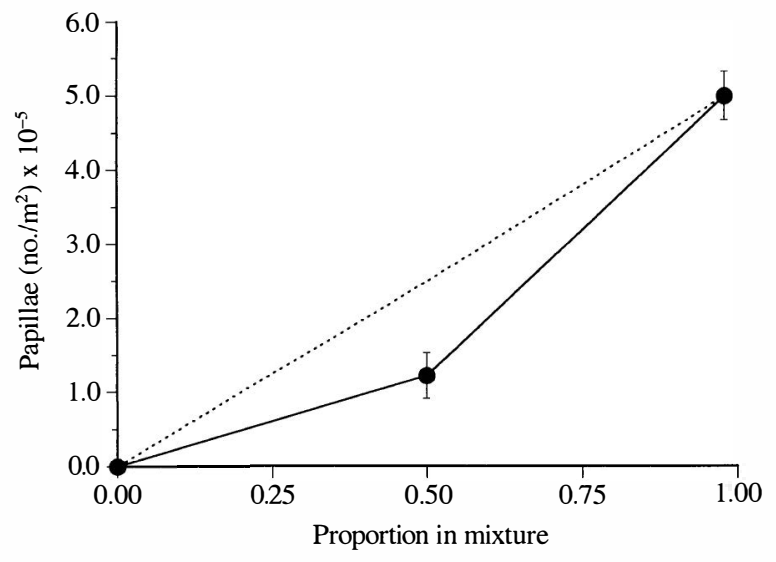

FIG. 9. Number of reproductive papillae on Mastocarpus stellatus fronds per square meter, grown either alone or in a 50:50 mixture with Chondrus crispus in the low zone at Pemaquid Point, Maine. The dashed line represents the predicted density of papillae per square meter for a given density of $M$. stellatus in the absence of $C$. crispus. Values represent the means $\pm 1 \mathrm{SE}(N=4$ for 1.0 proportion, and $N=5$ for 0.5 proportion of $M$. stellatus in mixture).

that for both species the presence of the other has no effect on the biomass yield of fronds in the mid-low zone. Although the yield of Mastocarpus stellatus either growing alone or in a 50:50 mix was less than that of $C$. crispus in the low zone (alone, $U=16, n=m$ $=4, P \leq 0.05 ; 50: 50 \mathrm{mix}, U=25, n=m=5, P \leq$ 0.01 ), it was greater than that of $C$. crispus in the midlow zone (alone, $U=24, n=m=5, P<0.03 ; 50: 50$ $\operatorname{mix}, U=22, n=m=5,0.05<P<0.10)$. However, the yields of each species growing alone in the midlow zone were much less than in the low zone (cf. Figs. 8 and 10). The yield of Chondrus crispus in the midlow zone $(+0.5 \mathrm{~m} \mathrm{MLW})$ was only $2 \%$ of that in the low zone $(0.0 \mathrm{~m} \mathrm{MLW})$. The yield of $M$. stellatus in the mid-low zone was only $13 \%$ of that in the low zone and, in contrast to fronds in the low zone, none of the experimental fronds in the mid-low zone developed papillae during the experiment.

\section{Mastocarpus recruitment and regeneration: effects of competitors and herbivorous gastropods}

The results of the deletion experiment indicate that treatment effects did not vary among different locations along the shoreline. No significant interactions were revealed by Tukey's test for nonadditivity between experimental treatments and block (i.e., spatial location along the shore) for any response variable (upright fronds of Mastocarpus stellatus, $F_{1,7}=4.47 \times 10^{-5}, P$ $>0.99$; crusts of $M$. stellatus, $F_{1,7}=0.009, P>0.75$; Chondrus crispus, $F_{1,7}=0.03, P>0.75$, Fucus spp. $\left.F_{1,7}=0.02, P>0.75\right)$.

Neither upright fronds nor crusts of Mastocarpus stellatus recruited to plots where Chondrus crispus and crusts of $M$. stellatus were completely removed whether or not herbivorous gastropods were present (Fig. 11).
In fact, upright fronds of $M$. stellatus recruited only sparsely to the five $20 \times 20 \mathrm{~cm}$ total removal plots established in the "Mastocarpus-dominated" mid-high zone after $2 \mathrm{yr}$ (mean $\pm 1 \mathrm{SE}=45 \pm 23$ recruits $\mathrm{m}^{-2}$, covering $5.2 \% \pm 3.3$ of the substrate). Neither phase of $M$. stellatus was present in abundance in plots with a canopy of $C$. crispus whether or not herbivorous gastropods were present (Fig. 12). After $2 \mathrm{yr}$, upright fronds of $M$. stellatus in the low zone increased in abundance (via holdfast regeneration) only when fronds of $C$. crispus were removed and grazers were present (Fig. 13; $F=5.50$, df $=4,16$ (re $\times$ hrb), $P$ $<0.01 ; F=3.70$, df $=2,16$ (hrb), $P<0.05)$. The abundance of $M$. stellatus did not vary with location along the shore $(F=0.67$, df $=2,16$ (blk), $P>0.50$, $(1-\beta)=1.00, \phi=4.33)$. The power of this test is great and is based on an assumed minimum significant effect size of $5 \%$ mean difference in percent cover from the smallest to the largest treatment mean.

In contrast to Mastocarpus stellatus, spores of Chondrus crispus recruited to total removal plots within 1 yr. After 2 yr, the percent cover of $C$. crispus in these plots increased to $\sim 50 \%$ (Fig. 11). Regeneration of $C$. crispus fronds from holdfasts occurred even more rapidly, approaching $60-80 \%$ cover within 3 mo following removal and returning to pre-manipulation abundances within $1 \mathrm{yr}$ (Fig. 13). Percent cover of $C$. crispus in control plots typically remained $\geq 80 \%$ throughout the experiment (Fig. 12). Herbivores did not affect the abundance of new recruits, regenerating fronds, nor canopy fronds of $C$. crispus $(F=0.12$, df $=2,20$ (hrb), $P>0.75,(1-\beta)=0.30, \phi=1.04$; same assumptions as above). The patterns of abundance of C. crispus fronds in each treatment did not vary from place to place along the shore $(F=2.89, \mathrm{df}=2,20$ (blk), $P>0.05,(1-\beta)=0.24, \phi=0.90)$.

Recruitment by barnacles (Semibalanus balanoides), rockweeds (Fucus spp.), and mussels (Mytilus edulis)

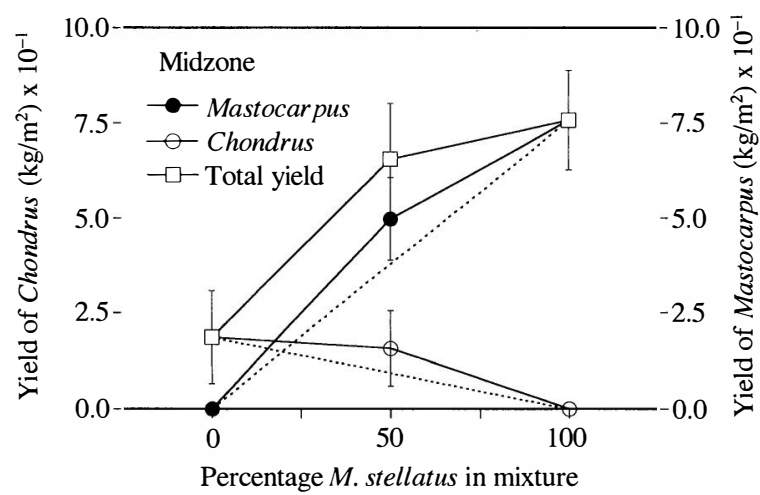

FIG. 10. Fresh mass yield of Chondrus crispus and Mastocarpus stellatus growing either alone or in a 50:50 mixture in the mid-low zone at Pemaquid Point, Maine. Squares represent the combined yield of both species for each mixture. Dashed lines represent the predicted yields of each species in the absence of the other. Values represent means $\pm 1 \mathrm{SE}$ of $N=5$. 


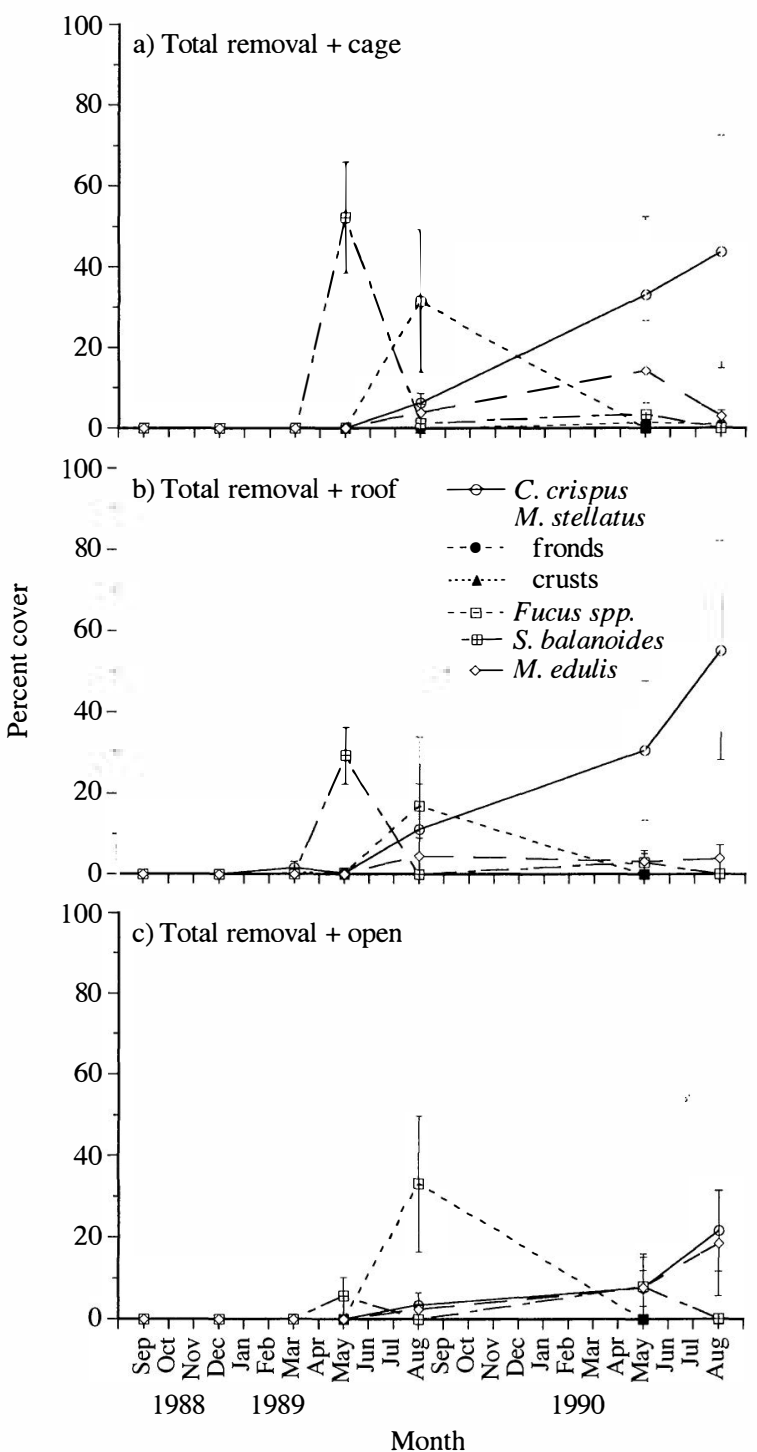

Fig. 11. Percent cover attributed to recruitment of Chondrus crispus, upright fronds of Mastocarpus stellatus, crusts of M. stellatus, Fucus spp., barnacles (Semibalanus balanoides), and mussels (Mytilus edulis) in the low zone at Chamberlain, Maine, from September 1988 to August 1990. Values represent mean $\pm 1 \mathrm{SE}(N=3)$ of percent cover in (a) total removal + cage plots, (b) total removal + roof plots, and (c) total removal + open plots.

largely occurred in plots in which Chondrus crispus was totally removed, although barnacles also recruited on top of $C$. crispus holdfasts. Only mussels persisted in these plots. They appeared after $1 \mathrm{yr}$ and remained at a low abundance throughout the experiment. Barnacles recruited abundantly the first spring (1989) following the manipulation, disappeared by the end of the summer, and recruited little the following year (1990). Fucus spp. did not recruit either to control or frond removal plots, and recruitment to total removal plots in the summer of 1989 was highly variable. Variance

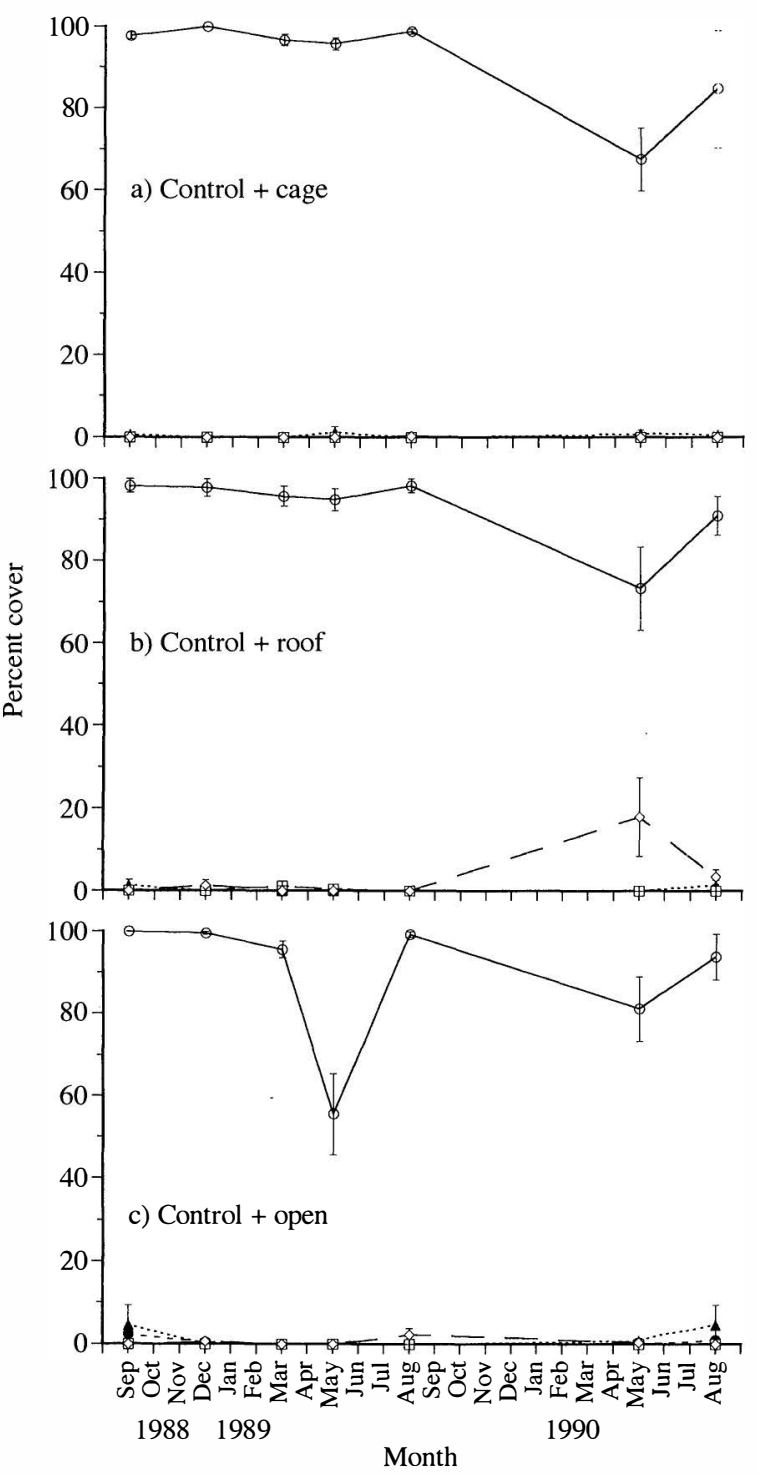

FIG. 12. Percent cover of Chondrus crispus (0), upright fronds of Mastocarpus stellatus $(\bullet)$, crusts of M. stellatus ( $\mathbf{(})$, Fucus spp. (ㅁ), barnacles (Semibalanus balanoides; \pm ), and mussels (Mytilus edulis; $\diamond)$ in "algae unmanipulated" plots in the low zone at Chamberlain, Maine, from September 1988 to August 1990. Values represent mean $\pm 1 \mathrm{SE}(N=3)$ of percent cover in (a) control + cage plots, (b) control + roof plots, and (c) control + open plots.

component estimates indicated high variability in the data associated with differences in recruitment to total removal plots within each block. Four of the total removal plots had 0 or $1 \%$ Fucus, the other five had $>30 \%$. The presence of herbivores had no effect on the abundance of Fucus spp. but the power of the test was weak $(F=0.57, \mathrm{df}=2,4(\mathrm{hrb}), P>0.50,(1-$ $\beta)=0.38, \phi=1.21)$. None of these Fucus recruits survived into 1990. Fucus failed to recruit to these plots again in 1990, and after 2 yr was completely absent. 


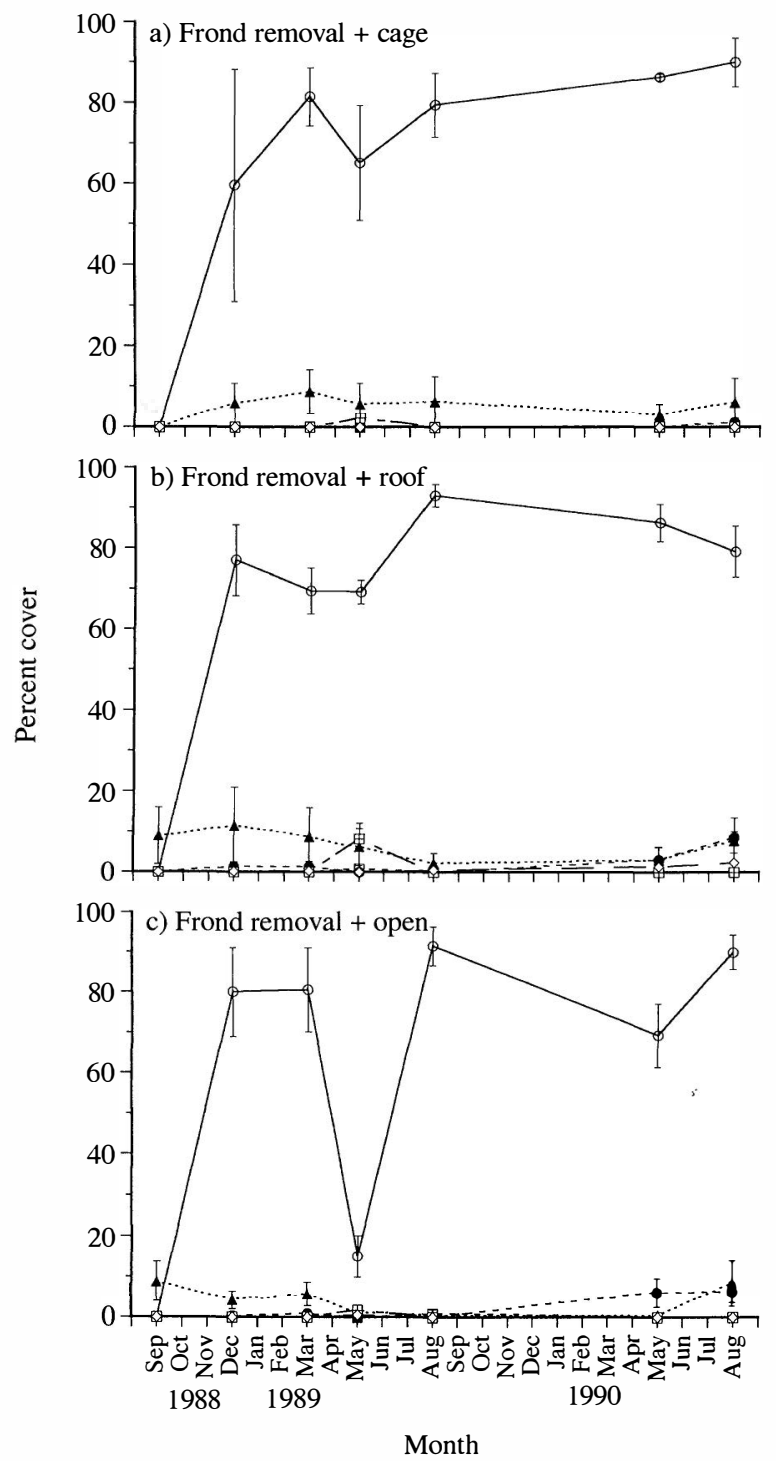

Fig. 13. Percent cover attributed to holdfast regeneration of Chondrus crispus (O), upright fronds of Mastocarpus stel-

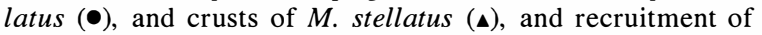
Fucus spp. (), barnacles (Semibalanus balanoides; $\forall$ ), and mussels (Mytilus edulis; $\diamond$ ) in the low zone at Chamberlain, Maine, from September 1988 to August 1990. Values represent mean \pm 1 SE $(N=3)$ of percent cover in (a) frond removal + cage plots, (b) frond removal + roof plots, and (c) frond removal + open plots.

\section{Artifacts of the experimental design}

The percent cover of both Chondrus crispus and Mastocarpus stellatus, and the total abundance of herbivorous gastropods were used to detect artifacts associated with the manipulations. Comparisons between open and roof plots suggests that the presence of cages did not affect the abundance of $M$. stellatus during the course of the experiment. Cages did affect estimates of the percent canopy cover by $C$. crispus. The canopy cover of C. crispus declined in uncaged (open) plots in spring because of invasion by an ephemeral green alga, Monostroma pulchrum, that occurs as an epiphyte on $C$. crispus. Consequently, our point-sample estimates of canopy cover in these plots did not fall on the $C$. crispus fronds lying underneath the epiphytes. In contrast, in roof and "cage" plots, M. pulchrum recruited onto the cages (instead of the Chondrus fronds) in April and May inhibiting further recruitment of annuals inside the cage. In these plots the canopy coverage of $C$. crispus remained $\geq 60 \%$ (Fig. 12).

Herbivores were often more abundant in total removal plots than in either frond removal or control plots (Fig. 14). Thus, the presence of perennial macroalgae influenced grazer density. No consistent difference in herbivore abundance was observed in roof plots compared to open plots. Overall, none of the artifacts introduced by the manipulations altered the outcome of the experiment with respect to the final abundance of Chondrus crispus and Mastocarpus stellatus.

\section{Consumption of red algae by Littorina spp.}

Neither Chondrus crispus nor Mastocarpus stellatus were readily consumed by Littorina littorea in single choice feeding assays (Fig. 15). The change in algal mass was not different between treatments with and without $L$. littorea in either species $(F=0.24, \mathrm{df}=1$, 12 (trt), $P>0.60,(1-\beta)=0.05, \phi=0.07)$, nor was there a significant difference between species $(F=$ 4.72, $\mathrm{df}=1,12(\mathrm{sp} \times \operatorname{trt}), P>0.05,(1-\beta)=0.05$, $\phi=0.04)$. Moreover, L. littorea exhibited no preference between $C$. crispus and $M$. stellatus when offered simultaneously in a multiple choice experiment (MannWhitney, $U^{\prime}=95, n=m=12, P>0.15$; data not shown). The power of these tests was very weak, but they assume that a $5 \mathrm{mg} \cdot \mathrm{g}^{-1} \cdot \mathrm{d}^{-1}$ difference between treatments is the minimum biologically significant effect size. Porphyra spp., on the other hand, was consumed by $L$. littorea significantly more than either $C$. crispus or M. stellatus (Porphyra spp. vs. C. crispus, $F=39.52, \mathrm{df}=1,12$ (sp $\times$ trt), $P<0.01$, Porphyra spp. vs. $M$. stellatus, $F=53.57, \mathrm{df}=1,12(\mathrm{sp} \times \mathrm{trt})$, $P<0.01)$.

As with Littorina littorea, Chondrus crispus and Mastocarpus stellatus were consumed little by $L$. obtusata in single choice tests (i.e., no difference between change in algal mass with and without herbivores), and no significant difference was observed in change in algal mass between species $(F=1.44, \mathrm{df}=1,12(\mathrm{sp}$ $\times$ trt $), P>0.20,(1-\beta)=1.00, \phi=7.25$, using same assumptions as above). Consumption of Porphyra spp. by $L$. obtusata was variable and there was no significant preference for ephemeral algae over perennial red algae by L. obtusata (Porphyra spp. vs. C. crispus, $H=0.18, P>0.50$, Porphyra spp. vs. M. stellatus, $H=0.54, P>0.10$ ). We assume that the laboratory conditions employed in these assays did not deter feeding by $L$. obtusata. 


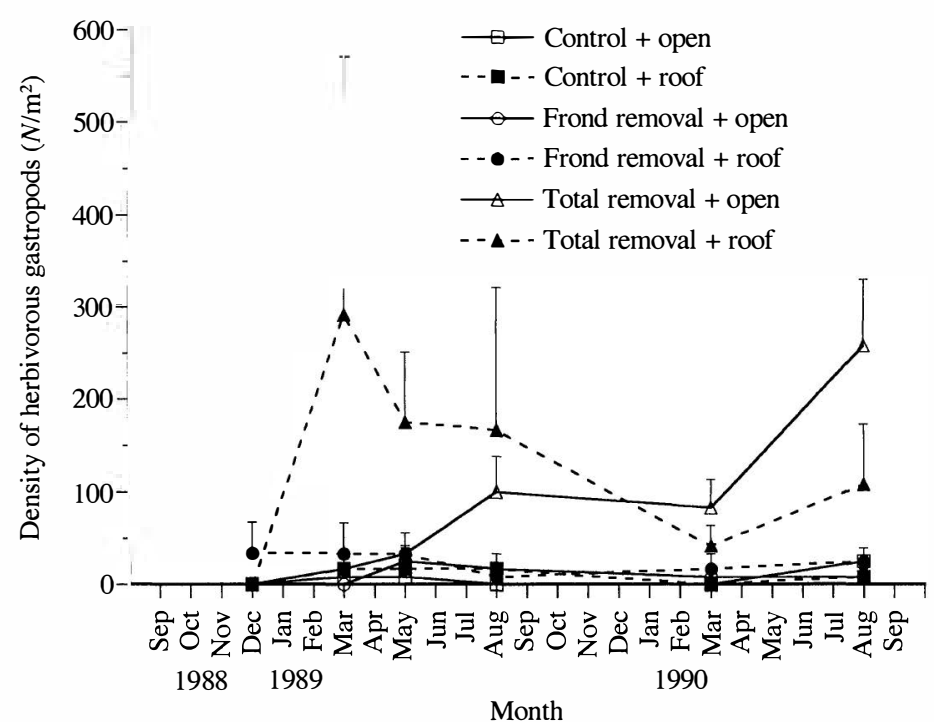

FIG. 14. Abundance of herbivorous gastropods in experimental plots in each month sampled at Chamberlain, Maine. Values represent the mean $\pm 1 \mathrm{SE}(N=3)$ density of gastropods in plots.

\section{Discussion}

Most evidence from studies of space-limited marine communities indicates that high mortality rates of dominant competitors from disturbances (usually predators or storm waves) prevent them from monopolizing space and enable other species to coexist (Paine 1966, Dayton 1971, Connell 1978, Lubchenco and Menge 1978, Sousa 1979). The results of our study of clonal seaweeds indicate that different processes reduce the strength of competition between Chondrus crispus and Mastocarpus stellatus in different environments. This enables them to coexist in a range of habitats spanning one vertical meter of the lower intertidal zone. We suggest that processes contributing to the low productivity, rather than high mortality, of the dominant competitor, C. crispus, maintain the coexistence of fronds in the mid-low intertidal zone $(+0.35$ to $+0.75 \mathrm{~m} \mathrm{MLW})$. In

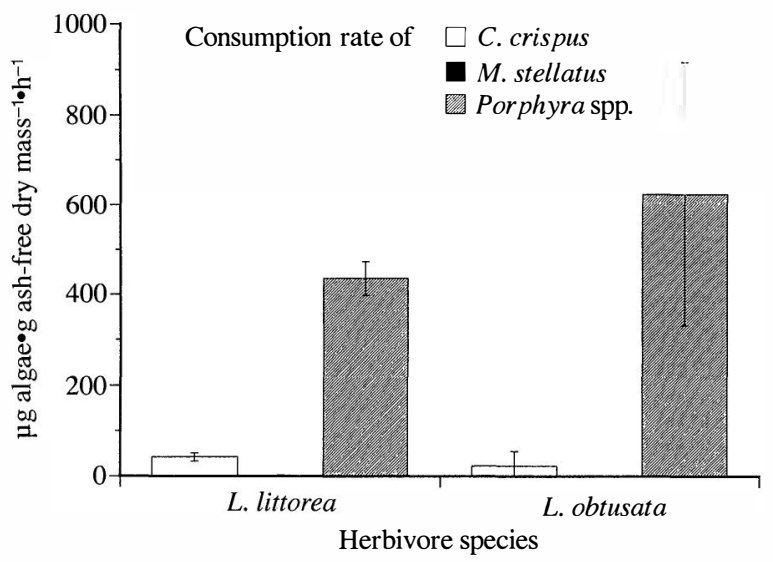

FIG. 15. Consumption rates of Littorina littorea and $L$. obtusata on Chondrus crispus, Mastocarpus stellatus, and Porphyra spp. Consumption rates on M. stellatus are too low to be visible in the figure. Values represent mean $\pm 1 \mathrm{SE}$ of $N=4$ replicates. contrast, as many as three different factors may reduce competition between these species in the low intertidal zone (less than $+0.35 \mathrm{~m} \mathrm{MLW)}$ ). First, competition between upright fronds of the two species in this zone is intense, but occurs infrequently because fronds of $M$. stellatus fail to consistently recruit. Low on the shore (less than $+0.25 \mathrm{~m} \mathrm{MLW}$ ) it is primarily the crusts of $M$. stellatus that coexist with $C$. crispus. Second, disturbances caused by winter storm waves remove many large fronds of $C$. crispus (Fig. 3a, also Dudgeon and Johnson 1992) and may be important to the coexistence of $C$. crispus, crusts, and the few upright fronds of $M$. stellatus. Finally, competition between crusts and fronds may be a weak interaction because of the different traits correlated with each morphology (Littler and Littler 1980, Steneck and Dethier 1994, Dudgeon et al. 1995).

\section{Coexistence of upright fronds in the mid-intertidal zones}

The replacement competition experiment tested the ability of fronds of Chondrus crispus (the faster growing, competitively dominant species; Mathieson and Burns 1975, Lubchenco 1980; Results: Competition among . . .) to overgrow those of Mastocarpus stellatus in both the low and mid-low intertidal zones. In contrast to the low zone (discussed below), C. crispus and $M$. stellatus did not compete in the mid-low zone (approximately $+0.5 \mathrm{~m} \mathrm{MLW)} \mathrm{because} C$. crispus could not overgrow $M$. stellatus. As a mechanism of competition, overgrowth can act only in habitats in which a species grows sufficiently rapidly to sustain enough biomass such that it can overgrow another species (i.e., competitive ability depends on productivity; Grime 1979, Huston 1979, Keddy 1989) prior to its death. We infer from three different lines of evidence that the inability of $C$. crispus to overgrow M. stellatus in the 
mid-low zone resulted, not from high frond mortality, but from low frond productivity. First, the biomass produced by $C$. crispus (used as a proxy for predicting patterns of primary production) during the summer and early fall declined sharply between the low and midlow intertidal zones. Moreover, biomasses produced in the midzone during the summer by $C$. crispus and $M$. stellatus, respectively, were not significantly different. Second, in both field and laboratory experiments $C$. crispus was not consumed by herbivorous gastropods suggesting that they are not an important source of frond mortality. Third, the lack of available space for colonization and the low temporal variation in biomass in the mid-low zone over approximately two years suggest that abiotic disturbances (e.g., wave forces) did not create open patches in seaweed beds by dislodging fronds. The dislodgement of many algae, including $C$. crispus and $M$. stellatus, is size dependent (Carrington 1990, Dudgeon and Johnson 1992). The low productivity of $C$. crispus in the mid-low zone and above results in small-sized fronds occurring in dense stands that are rarely dislodged because they experience low drag forces (Carrington 1990, Dudgeon and Johnson 1992; A. Johnson, personal communication).

The lower productivity of Chondrus crispus higher on the shore, compared to that in the low zone, stems from the more frequent and longer emersion during low tides. During spring tides seaweeds in both the midand low zones are emersed, but those higher on the shore are emersed for up to one hour longer $(\sim 20-30$ min each on the ebbing and flooding tides; S. R. Dudgeon, personal observation) per tide. During neap tides seaweeds in the mid-low and mid-high zones are often exposed at low tide for an hour or two, whereas those in the low zone remain submerged. Over time the accumulated difference can significantly affect the vitality of $C$. crispus fronds (Dudgeon et al. 1990). We hypothesize that the longer and more frequent atmospheric exposures of $C$. crispus fronds higher on the shore reduce their productivity relative to low zone fronds, both directly and indirectly. Production is reduced directly by the comparatively limited time that C. crispus is submerged and can acquire nutrients (e.g., $\mathrm{HCO}_{3}^{-}$, as an inorganic carbon source for photosynthesis; $\mathrm{N}$, nitrogen as $\mathrm{NH}_{4}{ }^{+}$or $\mathrm{NO}_{3}{ }^{-}$) obtained from seawater. It is also reduced indirectly by physiological stress (e.g., desiccation at high summer temperatures $\sim 30^{\circ} \mathrm{C}$, freezing in winter) that constrains the acquisition of resources even for several hours after fronds are submerged again in seawater (Davison et al. 1989, Dudgeon et al. 1989, Dudgeon et al. 1995). Freezing during low tide emersion can also have consequences for future growth. Chronic exposure (i.e., long-term repeated exposures $\sim 20 \mathrm{~d}$ ) of $C$. crispus in the midlow and mid-high zones to freezing during the winter months bleaches the apical region of fronds (Dudgeon et al. 1990). This metabolically inactive tissue is sloughed off when growth resumes in the spring, re- ducing the likelihood of overgrowing $M$. stellatus the following summer since the plants begin growth at a slightly smaller size than in the previous fall (S. R. Dudgeon, unpublished data). In contrast, fronds of $M$. stellatus rarely bleach and do not slow growth as much as $C$. crispus during winter presumably because of the greater tolerance of their plasma membrane and efficiency of energy transfer in the photosynthetic light harvesting reactions following freezing exposures (Dudgeon et al. 1989, 1990, 1995).

\section{Limited abundance of $\mathrm{M}$. stellatus fronds in the low intertidal zone}

Collectively, our data from three experiments (replacements, removals, and transplants) allow us to distinguish among five different factors (competition by overgrowth of fronds, or preempting space from sporelings, recruitment, herbivory, and physiological stress) that are potential explanations for the low abundance of upright fronds of Mastocarpus stellatus in the low intertidal zone (less than $+0.35 \mathrm{~m} \mathrm{MLW}$ ). Of these five factors, two are important. Chondrus crispus outcompetes $M$. stellatus by overgrowing established fronds and in years of potentially heavy recruitment of $M$. stellatus fronds, established beds of $C$. crispus and/or crusts of $M$. stellatus in the low zone preempt space. However, preemption of space may be an infrequently occurring competitive mechanism because $M$. stellatus fronds fail to consistently recruit to this zone. Herbivory appears unimportant to the distribution and abundance of $M$. stellatus.

In contrast to the mid-low zone discussed above, Chondrus crispus in the low zone $(\sim 0.0 \mathrm{~m} \mathrm{MLW})$ is highly productive. The biomass yield of $C$. crispus after one year in this zone was 50-fold that of the yield of mid-low zone fronds (cf. Figs. 8 and 10), despite the potential loss from winter storm waves of these rapidly growing, large fronds. The yield of fronds of Mastocarpus stellatus in the low zone, though not as high as C. crispus, was $\sim 7.5$ times that of conspecific fronds in the mid-low zone. Nevertheless, the overgrowth of fronds of $M$. stellatus by those of $C$. crispus in mixed stands of the two species in the low zone suppressed its growth and potential reproductive output. This result provides evidence of the competitive dominance of $C$. crispus and confirms earlier reports that $C$. crispus is the dominant competitor among perennial algae on emergent substrate (Mathieson and Prince 1973, Lubchenco and Menge 1978, Lubchenco 1980).

The high survivorship of $M$. stellatus fronds transplanted to the Chondrus zone is not inconsistent with the conclusion of competitive dominance by $C$. crispus. Indeed, these fronds may have suffered from competition with $C$. crispus, but this experiment was not designed to detect competition unless it caused a mortality event. Competition between plant species rarely causes mortality because inferior competitors of ten survive as suppressed shoots for long periods beneath a 
canopy (Harper 1977). Alternatively, transplants may have escaped competing with $C$. crispus because of three experimental artifacts. First, transplants in petri dishes were raised off the substrate by the height of the petri dish, which can be a significant fraction of the height of the Chondrus canopy. Second, transplants were placed in cleared patches. Transplants, therefore, did not experience the true effect of living underneath a $C$. crispus canopy. Third, no $C$. crispus occurred on the dish with $M$. stellatus transplants (i.e., fronds were not dense enough to detect an effect). Rocks in dishes were entirely covered with $M$. stellatus holdfasts leaving only the surface of the marine epoxy for recruitment. Recruitment of $C$. crispus onto this surface took more than one year, and occurred only after facilitation by other organisms (e.g., diatoms) and very infrequently.

It has been inferred from the zonation of upright fronds of Chondrus crispus and Mastocarpus stellatus (Mathieson and Prince 1973), and from experiments with C. crispus and Fucus spp. (Lubchenco 1980), that the mechanism of competitive dominance by $C$. crispus is the preemption of space. Two additional lines of evidence support this hypothesis with respect to $M$. stellatus. Both transplants of $M$. stellatus fronds at $\mathrm{Pe}-$ maquid Point and the dominance by $M$. stellatus fronds of the low zone at sites where C. crispus is rare or absent, such as Schoodic Point (discussed below, Discussion: Coexistence of Chondrus and Mastocarpus), indicate that the low intertidal zone is as, or more, favorable a place for these fronds to live than higher on the shore. Moreover, crusts of $M$. stellatus are the major occupier of space apart from C. crispus in the low zone. However, the lack of recruitment of upright fronds of $M$. stellatus after removing all organisms from the rock and excluding herbivorous gastropods suggest that presettlement, or very early post-settlement factors limit the number of individuals in the low zone more than inter-, or intraspecific competition (with crusts), or herbivory by gastropods. This result was surprising given that two different sources of spores that give rise to upright fronds are locally abundant: apomictic carposporophytes (i.e., upright fronds) in the mid-low zone and crustose tetrasporophytes in the low zone, often adjacent to experimental plots. Also, few recruits of upright fronds were observed in total removal plots in the mid-high zone where upright fronds predominate. The only treatment showing increased abundance of upright $M$. stellatus fronds was the removal of C. crispus fronds (but not holdfasts) in the presence of herbivores. It is likely that this reflected the regeneration of fronds from holdfasts previously suppressed by the canopy of $C$. crispus, rather than recruitment of sporelings. We lack unequivocal evidence for either interpretation; however, the lack of recruitment of $M$. stellatus in other treatments supports the interpretation of holdfast regeneration.

We suggest that the failure of Mastocarpus stellatus to recruit as either upright fronds or crusts is attributable to reproductive failures, rather than early postsettlement mortality. Since red algae lack motile spores, and spermatia must fertilize carpogonia on the female gametophyte, fertilization success is likely very low (Searles 1980). Laboratory culture studies of $M$. stellatus have found that germination rates of tetraspores, in particular, are low (Maggs 1988), and field studies on the west coast have noted the complete absence of recruitment of $M$. papillatus tetrasporophytes (Dethier 1994). Low viability of both carpospores (either apomictic or sexually produced) and tetraspores may underlie the poor recruitment of $M$. stellatus observed during this study. Complex patterns of reproduction and development characterize most species of the genus Mastocarpus (West 1972, Polanshek and West 1975, West et al. 1977, Guiry and West 1983, West et al. 1983), but the ecological significance of these patterns to field populations is virtually unknown.

Although we cannot exclude that small grazers, like amphipods or isopods, may consume cohorts of sporelings, two lines of evidence are inconsistent with this hypothesis. First, the peak abundances of amphipods and isopods coincide with peaks in ephemeral algal abundance in summer and early fall, overlap a little with the "settlement window" of carpospores, and not at all with that of tetraspores. Second, these crustaceans of ten use morphologically complex perennial seaweeds as habitat rather than food (Hacker and Steneck 1990).

The results of our deletion experiment are similar to those of Lubchenco (1980), done at a different time of year on different parts of the shore at Chamberlain, with respect to the population dynamics of Chondrus crispus. In both studies, control plots persisted for years with no significant change, $C$. crispus regenerated rapidly from holdfasts inhibiting recruitment by other species, recolonization of total removal plots by C. crispus from spores took longer than regeneration, and herbivorous gastropods had no effect on the regrowth of $C$. crispus either from holdfasts or spores. We also found similar results with respect to colonization by other species of total removal plots with a few important differences. Fucus spp. (at our site at Chamberlain, primarily $F$. vesiculosus rather than $F$. evanescens) did recruit to total Chondrus removal plots, and no other treatments, in the summer (1989) following the manipulation, but recruitment was highly variable from place to place along the shore. The presence of herbivores had no effect on the abundance of Fucus recruits. These recruits did not survive, and Fucus did not recruit during 1990 and thus was completely absent from experimental plots within one year. Collectively, our data showing variable recruitment of Fucus spp., failed recruitment of Mastocarpus stellatus, and those of Lubchenco (1980) showing heavy recruitment by Fucus spp., emphasize the importance of variable recruitment of propagules to generating pattern on New 
England rocky intertidal shores (see also Vadas et al. 1990).

\section{Coexistence of Chondrus and Mastocarpus in the low zone}

Like many seaweed assemblages, Chondrus crispus and Mastocarpus stellatus overlap considerably in their use of essential resources: space for attachment, light, and nutrient supplies. They show no evidence of specialization along any of these niche axes. This prompts the question of how M. stellatus, or any seaweed, coexists with $C$. crispus in habitats where the latter species is highly productive and not eaten. Disturbance to C. crispus populations from winter storm waves, at least in part, probably maintains their coexistence. Wave forces may reduce the canopy cover of $C$. crispus in the lowest intertidal zone by $\sim 30 \%$ (Dudgeon and Johnson 1992) and biomass by $50 \%$ (Fig. 3a). Unlike conspecific fronds higher on the shore, C. crispus fronds in the low zone are more susceptible to dislodgement by the hydrodynamic forces of waves because they grow to a much larger size (up to $15 \mathrm{~cm}$ tall, Taylor 1957). For C. crispus fronds, high productivity is correlated with high disturbance potential. In fact, $C$. crispus changes its morphology during growth at optimal temperatures (such as occur during summer in the Gulf of Maine) by increasing frond surface area per unit biomass, thereby increasing the capacity for resource acquisition, but also making large fronds more susceptible to dislodgement (Kübler and Dudgeon 1996). In contrast, fronds of $M$. stellatus are less susceptible to dislodgement than those of $C$. crispus of equal biomass (Dudgeon and Johnson 1992). Differences between these species in the probability of dislodgement of upright fronds may temporarily release small $M$. stellatus fronds suppressed beneath the $C$. crispus canopy from competition following a disturbance.

At present, we know little about the interaction between Chondrus crispus and crusts of Mastocarpus stellatus. Field experiments testing if crusts of $M$. stellatus could overgrow holdfasts of conspecific upright fronds or C. crispus did not yield data after one year because lateral growth of neither crusts nor holdfasts could be detected (S. R. Dudgeon, unpublished data). Competition between encrusting holdfasts and crustose thalli for space almost certainly occurs, but may occur over very long timescales because of their persistence and slow growth. Crusts of the genus Mastocarpus grow extremely slowly, but are very long-lived (Paine et al. 1979). These crusts are also thicker than most crusts, including holdfasts of $C$. crispus (S. R. Dudgeon, unpublished data), which may allow M. stellatus crusts to outcompete thinner ones (Steneck et al. 1991). Wave-generated disturbances to $C$. crispus populations may affect the growth of crusts of $M$. stellatus by affecting the flow regime and, hence the nutrient supply, and by removing barriers (i.e., upright fronds). How- ever, C. crispus may regenerate upright fronds on the edge of a holdfast system following a disturbance faster than $M$. stellatus crusts can grow laterally across it.

Competition among Chondrus crispus and crusts of M. stellatus for resources other than space, like light or nutrients, may be a weak interaction because of characteristics correlated with a crust morphology. For instance, photosynthesis of crusts of $M$. stellatus during the fall and winter becomes light-saturated at $\sim 20$ $\mu \mathrm{mol}$ photons $\cdot \mathrm{m}^{-2} \cdot \mathrm{s}^{-1}(\sim 1 \%$ of full sunlight $)$ and shows no photoinhibition up to $1500 \mu \mathrm{mol}$ photons $\cdot \mathrm{m}^{-2} \cdot \mathrm{s}^{-1}$ (Dudgeon et al. 1995, S. R. Dudgeon, unpublished data). The much lower light intensity needed to saturate photosynthesis of crusts compared to other algal morphs (e.g., saturation intensity for upright fronds of C. crispus and M. stellatus $\sim 80-100 \mu \mathrm{mol}$ photons $\cdot \mathrm{m}^{-2} \cdot \mathrm{s}^{-1}$ ) may reduce the strength of competition and facilitate the coexistence of crusts and fronds.

Our experimental data suggest the ecological processes that maintain patterns of coexistence of two common red seaweeds in the low intertidal zone. However, they say little about the processes underlying the origin of these patterns on rocky shores (e.g., Petraitis and Dudgeon 1999). We believe that the interesting pattern of dominance of Mastocarpus stellatus and relative absence of Chondrus crispus in the low intertidal zone at Schoodic Point reflects the importance of regional biological and oceanographic, as well as historical, processes. Once either species becomes established at a site, further recruitment may only need to be episodic because the perennial holdfast continually regenerates fronds, thereby maintaining a constant supply of individuals, even in the absence of settling spores. At Grindstone Neck, in Frenchman's Bay just northwest of Schoodic Point, C. crispus is very abundant (Lubchenco and Menge 1978) and coexists largely with crusts of M. stellatus (S. R. Dudgeon, personal observation). Upright fronds of $M$. stellatus, which are usually restricted to more exposed shores (Burns and Mathieson 1972), are uncommon at Grindstone Neck. On the east side of Schoodic Point (where our site is) and sites further northeast (e.g., Quoddy Head) C. crispus is replaced by fronds of $M$. stellatus and other red seaweeds. An exception to this pattern is Point LePreau, New Brunswick where C. crispus is also abundant. Our site at Point LePreau was adjacent to the release site of thermal effluent from a nuclear power plant. From the east side of Schoodic Point into the Bay of Fundy surface water temperatures during the growing season are considerably lower than to the west because the peninsula is directly in the path of the cold current flowing down from the Bay of Fundy (Apollonio 1979). The potential for long distance dispersal of C. crispus from sites further east is probably low because C. crispus is uncommon "upstream" of Schoodic Point. Moreover, previous work has noted that cold water temperatures $\left(<4^{\circ} \mathrm{C}\right)$ may impair spore attachment of C. crispus (Mathieson and Prince 1973). This 
regional pattern of the species' relative abundance parallels that observed biogeographically with increasing latitude in the North Atlantic (Lüning 1990).

\section{Productivity, disturbance, and the strength of competition}

Two models of competition among species of terrestrial plants generate different predictions about interaction strength in environments that differ in the supply rate of resources and, hence, productivity of the plants. One model predicts competition to be more intense in habitats where plants are productive because only these habitats support high growth rates and the accumulation of biomass necessary to overgrow competitors (Grime 1979, Huston 1979, Keddy 1989). In contrast, the second model predicts no change in interaction strength among competitors along gradients of productivity (Tilman 1987, 1988, Wilson and Tilman 1991). Instead, the nature of competition changes from above ground to below ground as plants compete for limited resources in the soil. Since benthic seaweeds on rocky intertidal shores and subtidally are attached to rock, there is no below ground competition. Our results do indicate that the strength of competition increases with increasing productivity of seaweeds. Moreover, interaction strength may vary on small spatial scales (i.e., within a few meters), such as within the intertidal zone.

Our study points to three features that are principally important to the organization of rocky shore seaweed communities and to ecological communities in general; the supply of resources, the potential for disturbance, and the morphological and ecological traits of organisms. Differences in morphology and the allocation of metabolic energy to different traits of species (i.e., correlated suites of life history traits, or "strategies," sensu Grime 1979) control their productivity and growth, and determine their tolerance to disturbance in different environments (Littler and Littler 1980, Steneck and Dethier 1994). Interactions between species occur in the context of these environmentally dependent responses of species. Environmental gradients profoundly affect the strength, or even the nature, of species interactions (Tilman 1985, Wilson and Keddy 1986, Bertness 1989, Wootton 1991, Menge 1992, Bertness and Hacker 1994, Hacker and Bertness 1995), the diversity of species, and the trophic structure of communities (McNaughton 1985, Carpenter et al. 1987, Power 1992). Such gradients may also contribute to different ecological processes controlling, not only the coexistence of the same competitors in different places, but also to the organization of communities of similar taxa in different biogeographic regions.

\section{ACKNOWLEDGMENTS}

We thank the following people who provided help in the field or laboratory: K. Becketti, K. DeKelaita, S. Hacker, J. Kübler, M. Lesser, J. Podolak, and W. Wright. A. R. O. Chapman, G. Chapman, S. Hacker, J. Kübler, M. Lesser, G. Pear- son, P. Petraitis, C. Pfister, E. Serraõ, A. J. Underwood, and $\mathrm{R}$. Wahle contributed intellectually to this research. To all we are grateful. The quality of this manuscript was greatly improved by comments from M. Dethier, B. Menge, and an anonymous reviewer. This research was supported by NSF OCE-9012622 to I. R. Davison, Maine Agricultural Experiment Station funds to R. L. Vadas and a University of Maine Center for Marine Studies Graduate Research Assistantship to S. R. Dudgeon.

\section{Literature Cited}

Apollonio, S. 1979. The Gulf of Maine. Courier of Maine Books, Rockland, Maine, USA

Armstrong, R. A., and R. McGehee. 1980. Competitive exclusion. American Naturalist 115:151-170.

Bertness, M. D. 1989. Intraspecific competition and facilitation in a northern acorn barnacle population. Ecology 70: 257-268.

Bertness, M. D., and S. D. Hacker. 1994. Physical stresses and positive associations among marsh plants. American Naturalist 144:363-372.

Burns, R. L., and A. C. Mathieson. 1972. Ecological studies of economic red algae. III. Growth and reproduction of natural and harvested populations of Gigartina stellata (Stackhouse) Batters in New Hampshire. Journal of Experimental Marine Biology and Ecology 9:77-95.

Carpenter, S. R., J. F. Kitchell, J. R. Hoodgson, P. A. Cochran, J. J. Elser, M. M. Elser, D. M. Lodge, D. Kretchmer, X. He, and C. N. Von Ende. 1987. Regulation of lake primary productivity by food web structure. Ecology 68:18631876.

Carrington, E. 1990. Drag and dislodgement of an intertidal macroalga: consequences of morphological variation in Mastocarpus papillatus Kützing. Journal of Experimental Marine Biology and Ecology 139: 185-200.

Caswell, H. 1978. Predator-mediated coexistence: a nonequilibrium model. American Naturalist 112:127-154.

Chapman, A. R. O. 1989. Abundance of Fucus spiralis and ephemeral seaweeds in a high eulittoral zone: effects of grazers, canopy and substratum type. Marine Biology 102: $565-572$.

Connell, J. H. 1961. The influence of interspecific competition and other factors on the distribution of the barnacle Chthamalus stellatus. Ecology 42:710-723.

1978. Diversity in tropical rain forests and coral reefs. Science 199:1302-1310.

Davison, I. R., S. R. Dudgeon, and H.-M. Ruan. 1989. The effect of freezing on seaweed photosynthesis. Marine Ecology Progress Series 58:123-131.

Dayton, P. K. 1971. Competition, disturbance, and community organization: the provision and subsequent utilization of space in a rocky intertidal environment. Ecological Monographs 41:351-389.

Dethier, M. N. 1994. The ecology of intertidal algal crusts: variation within a functional group. Journal of Experimental Marine Biology and Ecology 177:37-71.

de Wit, C. T. 1960. On competition. Agricultural Research Reports (Verslagen van Landbouwkundige Onderzoekingen) 66.8, Wageningen, The Netherlands.

Dudgeon, S. R., I. R. Davison, and R. L. Vadas. 1989. Effect of freezing on photosynthesis of intertidal macroalgae: relative tolerances of Chondrus crispus and Mastocarpus stellatus (Rhodophyta). Marine Biology 101:107-114.

Dudgeon, S. R., I. R. Davison, and R. L. Vadas. 1990. Freezing tolerance in the intertidal red algae Chondrus crispus and Mastocarpus stellatus: relative importance of acclimation and adaptation. Marine Biology 106:427-436.

Dudgeon, S. R., and A. S. Johnson. 1992. Thick versus thin: Thallus morphology and tissue mechanics influence differential drag and dislodgement of two co-dominant sea- 
weeds. Journal of Experimental Marine Biology and Ecology 165:23-43.

Dudgeon, S. R., J. E. Kübler, R. L. Vadas, and I. R. Davison. 1995. Physiological tolerances to environmental variation in intertidal red algae: does thallus morphology matter? Marine Ecology Progress Series 117:193-206.

Grime, J. P. 1979. Plant strategies and vegetation processes. John Wiley and Sons, New York, New York, USA

Guiry, M. D., and D. J. Garbary. 1990. A preliminary phylogenetic analysis of the Phyllophoraceae, Gigartinaceae and the Petrocelidaceae (Rhodophyta) in the North Atlantic and North Pacific. Pages 265-288 in D. J. Garbary and G. R. South, editors. Evolutionary biogeography of the marine algae of the North Atlantic. Springer-Verlag, Berlin, Germany.

Guiry, M. D., and J. A. West. 1983. Life history and hybridization studies on Gigartina stellata and Petrocelis cruenta (Rhodophyta) in the North Atlantic. Journal of Phycology 19:474-494.

Hacker, S. D., and M. D. Bertness. 1995. A herbivore paradox: why salt marsh aphids live on poor quality plants. American Naturalist 145:192-210.

Hacker, S. D., and R. S. Steneck. 1990. Habitat architecture and the abundance and body-size-dependent habitat selection of a phytal amphipod. Ecology 71:2269-2285.

Harper, J. L. 1977. Population biology of plants. Academic Press, London, UK.

Hughes, T., and J. B. C. Jackson. 1980. Do corals lie about their age? Some demographic consequences of partial mortality, fission and fusion. Science 209:713-715.

Huston, M. A. 1979. A general hypothesis of species diversity. American Naturalist 113:81-101.

Keddy, P. A. 1989. Competition. Chapman and Hall, London, UK.

Kübler, J. E., and S. R. Dudgeon. 1996. Temperature dependent change in the complexity of form of Chondrus crispus fronds. Journal of Experimental Marine Biology and Ecology 207:15-24.

Levins, R. 1979. Coexistence in a variable environment American Naturalist 114:765-783.

Littler, M. M., and D. S. Littler. 1980. The evolution of thallus form and survival strategies in benthic marine macroalgae: field and laboratory tests of a functional form model. American Naturalist 116:25-44.

Lubchenco, J. 1978. Plant species diversity in a marine intertidal community: importance of herbivore food preferences and algal competitive abilities. American Naturalist 112:23-39.

. 1980. Algal zonation in the New England rocky intertidal community: an experimental approach. Ecology 61:333-344.

Lubchenco, J., and B. A. Menge. 1978. Community development and persistence in a low rocky intertidal zone. Ecological Monographs 59:67-94.

Lüning, K. 1990. Seaweeds: their environment, biogeography, and ecophysiology. John Wiley and Sons, New York, New York, USA.

Maggs, C. A. 1988. Intraspecific life history variability in the Florideophycidae (Rhodophyta). Botanica Marina 31 465-490.

Mathieson, A. C., and R. L. Burns. 1975. Ecological studies of economic red algae. V. Growth and reproduction of natural and harvested populations of Chondrus crispus Stackhouse in New Hampshire. Journal of Experimental Marine Biology and Ecology 17:137-156.

Mathieson, A. C., and J. P. Prince. 1973. Ecology of Chondrus crispus Stackhouse. Pages 53-79 in M. J. Harvey and J. McLachlan, editors. Chondrus crispus. Nova Scotia Institute of Science, Halifax, Nova Scotia, Canada.
McNaughton, S. 1985. Ecology of a grazing ecosystem: the Serengeti. Ecological Monographs 55:259-294.

Menge, B. A. 1976. Organization of the New England rocky intertidal community; role of predation, competition, and environmental heterogeneity. Ecological Monographs 42: 355-393.

1992. Community regulation: under what conditions are bottom-up factors important on rocky shores? Ecology 73:755-765.

Menge, B. A., and J. P. Sutherland. 1987. Community regulation: variation in disturbance, competition, and predation in relation to environmental stress and recruitment. American Naturalist 130:730-757.

Paine, R. T. 1966. Food web complexity and species diversity. American Naturalist 100:65-75.

1974. Intertidal community structure: experimental studies on the relationship between a dominant competitor and its principal predator. Oecologia 15:93-120.

. 1977. Controlled manipulations in the marine intertidal zone, and their contributions to ecological theory. Academy of Natural Sciences, Special Publication 12:245270.

Paine, R. T., and S. A. Levin. 1981. Intertidal landscapes: disturbance and the dynamics of pattern. Ecological Monographs 51:145-178.

Paine, R. T., C. J. Slocum, and D. O. Duggins. 1979. Growth and longevity in the crustose red alga Petrocelis middendorfii. Marine Biology 51:185-192.

Peterson, C. H., and P. E. Renaud. 1989. Analysis of feeding preference experiments. Oecologia 80:82-86.

Petraitis, P. S., and S. R. Dudgeon. 1999. Experimental evidence for the origin of alternative communities on rocky intertidal shores. Oikos 84:239-245.

Petraitis, P. S., R. E. Latham, and R. A. Niesenbaum. 1989. The maintenance of species diversity by disturbance. Quarterly Review of Biology 64:393-418.

Polanshek, A., and J. A. West. 1975. Culture and hybridization studies on Petrocelis (Rhodophyta) from Alaska and California. Journal of Phycology 11:434-439.

Power, M. 1992. Top-down and bottom-up forces in food webs: do plants have primacy? Ecology 73:733-746.

Provasoli, L. 1968. Media and prospects for the cultivation of marine algae. Pages 63-75 in A. Watanabe and A. Hattori, editors. Cultures and collections of algae. Japanese Society of Plant Physiology, Hakone, Japan.

Rice, E. L., and A. R. O. Chapman. 1985. A numerical study of Fucus distichus (Phaeophyta). Journal of the Marine Biological Association of the United Kingdom 65:433-459.

Roughgarden, J., S. D. Gaines, and H. Possingham. 1988. Recruitment dynamics in complex life cycles. Science 241: $1460-1466$.

Searles, R. 1980. The strategy of the red algal life history. American Naturalist 115:113-120.

Serraõ, E. A. 1996. Reproductive ecology of Fucus vesiculosus Linnaeus in the Baltic Sea. Dissertation. University of Maine, Orono, Maine, USA.

Sousa, W. P. 1979. Disturbance in marine intertidal boulder fields: the non-equilibrium maintenance of species diversity. Ecology 60:1225-1239.

Steneck, R. S., and M. N. Dethier. 1994. A functional group approach to the structure of algal-dominated communities. Oikos 69:476-498.

Steneck, R. S., S. D. Hacker, and M. N. Dethier. 1991. Mechanisms of competitive dominance between crustose coralline algae: an herbivore-mediated competitive reversal. Ecology 72:938-950.

Taylor, W. R. 1957. Marine algae of the northeastern coast of North America. University of Michigan Press, Ann Arbor, Michigan, USA. 
Tilman, D. 1985. The resource ratio hypothesis of plant succession. American Naturalist 125:827-852.

1987. On the meaning of competition and the mechanisms of competitive superiority. Functional Ecology 1: 304-315.

1988. Plant strategies and the dynamics and structure of plant communities. Princeton University Press, Princeton, New Jersey, USA.

Underwood, A. J. 1981. Techniques of analysis of variance in experimental marine biology and ecology. Oceanography and Marine Biology Annual Review 19:513-605.

Underwood, A. J., and E. J. Denley. 1984. Paradigms, explanations, and generalizations in models for the structure of intertidal communities in rocky shores. Pages 151-180 in D. Strong, D. Simberloff, L. Abele, and A. Thistle, editors. Ecological communities: conceptual issues and the evidence. Princeton University Press, Princeton, New Jersey, USA.

Vadas, R. L. 1992. Littorinid grazing and algal patch dynamics. Pages 197-209 in J. Grahame, P. J. Mill, and D. G. Reid, editors. Proceedings of the Third International Symposium on Littorinid Biology. Malacological Society of London, London, UK.

Vadas, R. L., and R. W. Elner. 1992. Plant-animal interactions in the north-west Atlantic. Pages 33-60 in D. M. John, S. J. Hawkins, and J. H. Price, editors. Plant-animal interactions in the marine benthos. Systematics Association Special Volume 46. Clarendon Press, Oxford, UK.

Vadas, R. L., and F. Manzer. 1971. The use of aerial color photography for studies on rocky intertidal benthic marine algae. Pages 255-266 in A. Anson, editor. Proceedings of the third biennial workshop on aerial color photography in the plant sciences and related fields. American Society of Photogrammetry, Gainesville, Florida, USA.
Vadas, R. L., W. A. Wright, and S. L. Miller. 1990. Recruitment of Ascophyllum nodosum: wave action as a source of mortality. Marine Ecology Progress Series 61:263-272.

West, J. A. 1972. The life history of Petrocelis franciscana. British Phycological Journal 7:299-308.

West, J. A., M. D. Guiry, and M. Masuda. 1983. Further investigations of the genetic affinities and life history patterns of the red alga Gigartina. Pages 137-166 in Proceedings of the Joint China-U.S. Phycology Symposium, Quindao. Science Press, Beijing, China.

West, J. A., A. Polanshek, and M. D. Guiry. 1977. The life history in culture of Petrocelis cruenta J. Agardh (Rhodophyta) from Ireland. British Phycological Journal 12:4553.

Wilson, S. D., and P. A. Keddy. 1986. Species competitive ability and position along a natural stress/disturbance gradient. Ecology 67:1236-1242.

Wilson, S. D., and D. Tilman. 1991. Components of plant competition along an experimental gradient of nitrogen availability. Ecology 72:1050-1065.

Winer, B. J. 1971. Statistical principles in experimental design. Second edition. McGraw-Hill, New York, New York, USA.

Witman, J. 1985. Refuges, biological disturbance, and rocky subtidal community structure in New England. Ecological Monographs 55:421-445.

1987. Subtidal coexistence: storms, grazing, mutualism and the zonation of kelps and mussels. Ecological Monographs 57:167-187.

Wootton, J. T. 1991. Direct and indirect effects of nutrients on intertidal community structure variable consequences of seabird guano. Journal of Experimental Marine Biology and Ecology 151:139-153. 